\title{
MASTER
}

\section{MINNESOTA RETROFIT INSULATION IN-SITU TEST PROGRAM: EXTENSION AND REVIEW}

\section{JOHN WEIDT ASSOCIATES, INC.}

\author{
PART OF \\ THE NATIONAL PROGRAM \\ FOR \\ BUILDING THERMAL ENVELOPE SYSTEMS \\ AND INSULATING MATERIALS
}

\section{Prepared for the}

OPERATED BY

UNION CARBIDE CORPORATION FOR THE UNITED STATES DEPARTMENT OF ENERGY
U.S. Department of Energy Conservation and Solar Energy Office of Buildings and Community Systems Buildings Division 


\section{DISCLAIMER}

This report was prepared as an account of work sponsored by an agency of the United States Government. Neither the United States Government nor any agency Thereof, nor any of their employees, makes any warranty, express or implied, or assumes any legal liability or responsibility for the accuracy, completeness, or usefulness of any information, apparatus, product, or process disclosed, or represents that its use would not infringe privately owned rights. Reference herein to any specific commercial product, process, or service by trade name, trademark, manufacturer, or otherwise does not necessarily constitute or imply its endorsement, recommendation, or favoring by the United States Government or any agency thereof. The views and opinions of authors expressed herein do not necessarily state or reflect those of the United States Government or any agency thereof. 


\section{DISCLAIMER}

Portions of this document may be illegible in electronic image products. Images are produced from the best available original document. 
Printed in the United States of America. Available from National Technical Information Service

U.S. Department of Commerce

5285 Port Royal Road, Springfield, Virginia 22161

NTIS price codes-Printed Copy: A03 Microfiche A01

This report was prepared as an account of work sponsored by an agency of the United States Government. Neither the United States nor any agency thereof, nor any of their employees, makes any warranty, expressed or implied, or assumes any legal liability or responsibility for any third party's use or the results of such use of any information, apparatus, product or process disclosed in this report, or represents that its use by such third party would not infringe privately owned rights. 
Contract No. W-7405-eng-26

\title{
MINNESOTA RETROFIT INSULATION IN-SITU TEST PROGRAM: EXTENSION AND REVIEW
}

John Weidt Associates, Inc.

Chaska, Minnesota 55318

Date Published: February 1980

\author{
Part of \\ The National Program for \\ Building Thermal Envelope Systems and Insulating Materials
}

Research sponsored by the Office of Buildings and

Community Systems, U.S. Department of Energy

OAK RIDGE NATIONAL LABORATORY

Oak Ridge, Tennessee 37830

operated by

UNION CARBIDE CORPORATION

for the

DEPARTMENT OF ENERGY

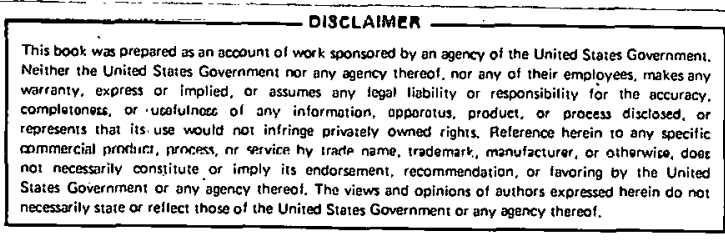




\section{THIS PAGE}

\section{WAS INTENTIONALLY \\ LEFT BLANK}


TABLE OF CONTENTS

Acknowledgements.................................. v

1.0 Introduction.................................

2.0 Moisture Content............................... 2

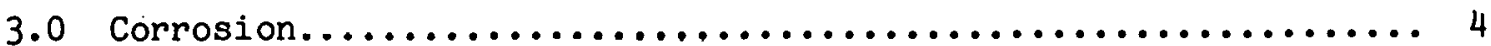

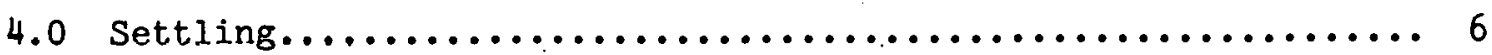

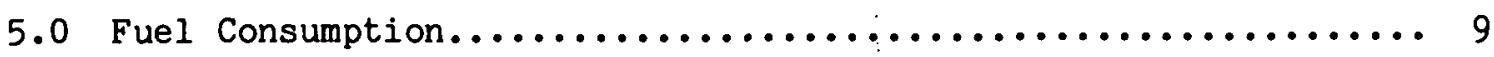

6.0 Density and Thermal Resistance Retests................. 10

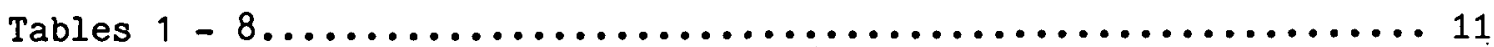

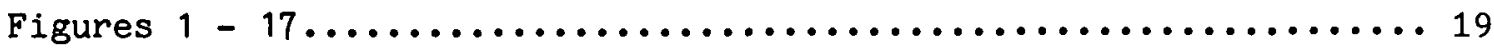

References......................................... 28

Appendix 1 Laboratory Experimental Procedures.................. 29 


\section{THIS PAGE \\ WAS INTENTIONALLY \\ LEFT BLANK}


We wish to thank the following persons and companies for their hard work and assistance in this study:

Robert Saxler, John Weidt Associates, Inc.

Craig Norsted, John Weidt Associates, Inc.

Gary Hittle, John Weidt Associates, Inc.

Kathy Thorstenson, John Weidt Associates, Inc.

Stu Spinney, Manager, Measurements Laboratory, Dynatech R/D Company

Bill Terranova, Project Technician, Dynatech R/D Company

Dave Benoy, Carpenter

Energy Conservation Consultants, Inc., Infrared Thermography

Members of Project Advisory Committee:

Wally Thometz, Minnegasco

Rick Hinkie, Northern States Power Co.

Jim Adams, Insulation Contractors Association Northwest

Bob Anderson, Diversified Insulation Corporation

Ray Wallentine, Carney Insulation

Mineral Insulation Manufacturers Association 
THIS PAGE

WAS INTENTIONALLY

LEFT BLANK 
FOREWORD

This is one of a series of reports to be published describing research, development, and demonstration activities in support of the National Program for Building Thermal Envelope Systems and Insulating Materials. The National Program involves several federal agencies and many other organizations in the public and private sectors who are addressing the national objective of decreasing energy wastes in the heating and cooling of buildings. Results described in this report are part of the National Program through delegation of management responsibilities for the DOE lead role to the Oak Ridge National Laboratory.

The effort described in this report was stimulated in part by objections to various information contained in HCP/W2843-01: Minnesota Retrofit Insulation In Situ Test Program (June 1978). Included as Appendix 2 is an "Errata Sheet" which refers to the original document.

Other reports in this series include the following which are available from NTIS.

1. DOE/CS-0059: The National Program Plan for Building Thermal Envelope Systems and Insulating Materials (January 1979).

2. ORNL/SUB-7556/I: Assessment of the Corrosiveness of Cellulosic Insulating MateriaTs (June 1979).

3. ORNL/SUB-7504/3: Recessed Light Fixture Test Facility (July 1979).

4. ORNL/SUB-7559/I : Problems Associated with the Use of UreaFormaldehyde Foam for Residential Insulation (September 1979).

5. ORNL/SUb-7551/I : Interim Progress Report on an Investigation of Energy Transpor $t$ in Porous Insulator Systems (October 1979).

Ted S. Lundy

Program Manager

Building Thermal Envelope Systems and Insulating Materials

Oak Ridge National Laboratory

E. C. Freeman

Program Manager, Buildings Division Architectural \& Engineering Systems Branch/BCS

Department of Energy 


\subsection{INTRODUCTION}

An insulation's performance is of primary concern to the consumer who is considering re-insulating his home. Few studies of re-insulation have been conducted outside the confines of a testing laboratory. A report entitled "Minnesota Retrofit Insulation In Situ Test Program", published by the Department of Energy in June 1978, detailed the findings of an in situ study of various thermal insulations installed in 55 residences in the Minneapolis/St. Paul area. The study, conducted in summer, $197 \%$, consisted of field observations and laboratory measurements of properties critical to the insulations' performance. Properties studied included density, thermal resistance, moisture content, shrinkage, flammability, friability and compression strength.

This study, hereinafter referred to as Phase $I$, was extended with a second phase to include further in situ study of retrofit insulations. Included in this extension work, hereinafter referred to as Phase II, was a further study of the molsture content of insulations, the corrosiveness of retrofit loose-fill cellulose insulation, thermography and field observations of sidewalls for signs of settling of retrofit loose-fill insulations, analysis of fuel consumption data for a number of the retrofitted homes, and density and thermal resistance retests of loose-fill insulations. This report details the field and laboratory findings of Phase II. 


\subsection{MOISTURE CONTENT}

The moisture content of an insulation can indicate problems with vapor transfer. High moisture content within an insulation can adversely affect its thermal performance (Ref, 1) and can cause corrosion, paint peeling, degradation of building components and growth of fungus and mold.

The Phase I data indicated very low moisture contents for all loose-fill insulation. Since the Phase I samples were taken during the summer months when moisture content may be expected to be low, moisture content samples were retaken during the spring when increased moisture may be driven into the insulating materials (Ref. 1).

Forty ceiling and 6 wall samples of cellulose and mineral fiber insulations were taken between 15 March and 1 May 1978. The samples were taken from a cross-section of the entire thickness of the retrofit insulation, sealed in thick-walled polyethylene jars and sent to the laboratory for testing. Wet bul.b and dry bulb readings were taken from the interior and exterior (or attic) environments immediately adjacent to the sample location. The moisture content was measured in the laboratory in the same waner as Phasc I, using the procedure outlined in Appendix 1. During Phase $\bar{I}$, all moisture content measurements were rounded to the nearest whole percentage, while Fhase II moisture content measurements are reported to the tenth of one percent accuracy.

Samples were removed from 6 sidewall cavities in 4 kumes in April of 1978. Two samples were rock/slag wool, and 4 samples were cellulose. The moisture content of these retested samples is shown in Table 1. As can be seen, the moisture 
content of the observed insulations in Phase II was still quite low and is generally comparable to or slightly lower than the measurements obtained during Phase I.

Samples were removed from 40 attics between 15 March and 1 May 1978. Twenty-three of these samples were loose-fill glass fiber, 14 were loose-fill cellulosic fiber and 3 were loose-fill rock/slag wool. The moisture content of these retested samples is shown in Tables 2 through 4 . As can be seen from the data, the moisture contents of all the glass and rock/slag fibers measured during Phase II is generally comparable to or lower than the moisture contents found during the Phase. I work. The moisture content of the cellulosic loose-fill materials measured during Phase II was higher than that measured during Phase I for 13 of the 14 samples, and ranged from 2.9 to $11.1 \%$. The Phase II cellulose samples had a moisture content on the order of $4 \%$ greater than the Phase I samples.

The measured moisture contents of both the Phase I and II samples indicated relatively low moisture content in the thermal insulations. No moisture problems were observed that could be related to the insulation. 


\subsection{CORROSION}

Cellulose insulation is comprised of products such as newsprint or wood fiber with chemicals added for flame retardation. It has been suggested that certain of these flame-retardant chemicals may be deleterious to metals such as copper, aluminum and steel and can result in corrosion (Ref. 3). Such corrosion could cause damage to electrical boxes, wiring and other metals commonly found in walls and attics.

Calibrated metal coupons nominally $2^{\prime \prime}$ x 2" were placed in 12 attics containing loose-fill cellulose insulation. One coupon each of steel, copper and aluminum was placed well below the surface of the insulation and left undisturbed for 12 to 13 months. The coupons were retrieved with the insulation that surrounded them, placed in polyethylene jars and shipped to the laboratory. Relative humidity readings were taken both during placement and retrieval of the coupons. The coupons were cleaned and weighed before placement in the attic and weighed again after removal. The condition of the coupons after removal was notcd. These results can be found in Table 5 .

Twenty-five percent of the aluminum coupons and $17 \%$ of the steel coupons exhibited minor pitting corrosion. No perforations were observed on any of the test metals. Discoloration was noted in both steel and copper coupons, the latter exhibiting the greatest amount of discoloration. The before and after weights of the coupons did not vary more than +- 2\%. The relative humidity of the attics ranged from 28 - 92\% at the time of placement and $40-71 \%$ at the time of retrieval. 
The coupons exhibited only minor changes in color and weight. The results of this project did not indicate problems with the sampled cellulose insulation relative to the corrosion of the copper, steel or aluminum coupons exposed to the insulation in situ for a period of approximately 1 year. 


\subsection{SETTLING}

Concern has been expressed over the possibility of settling of loose-fill insulating materials (Ref. 3). If excessive settling occurs, it can affect density, thermal resistance and overall performance of the insulation (Ref. 3 ). Work was done during Phase II to evaluate the methods by which settling might be observed and the extent to which settling takes place.

The project employed infrared thermography to observe potential areas of settling. Thermograms were made from the interior of the homes during periods when outdoor temperatures ranged from $27-33$ Deg. F. Areas of potential insulation voids were identified by the technician and noted on photographs of the interior.

The sidewalls of 7 homes were scanned in March, 1978. After careful analysis of the thermograms, 4 homes ( 1 rock/slag wool and 3 cellulose) were opened where the technician indicated voids in the insulation. A total of 6 openinga were made. The opening was made in such a way to confirm the existence and extent of the void and to allow removal of a sample of the insulation for testing. In 1 case, 2 openings were made in the same cavity, 1 at the top ( $23 W \times 1$ ) and 1 at the bottom (23WX2); in another case, 2 openings were made, 1 at the cav1ty showing an insulation void ( $6 \mathrm{WX} 2)$ and 1 at the top of an adjacent cavity (6WX1). The density of the 6 samples was measured. The results of the density tests can be found in Table 6. A detailed desoription of laboratory procedures can be found in Appendix 1.

The thermograms of the homes scanned showed voids in 1 or more cavities in each 
home. No consistent pattern of settling was evident; that is, signs of voids appeared randomly at the top of a few wall cavities while wall cavities adjacent to the void area appeared completely filled.

The physical openings made in 4 homes confirmed that the thermogram had accurately portrayed the voids. Figures 1 through 17 are photographs, thermograms and field worksheets illustrating the areas opened. In 1 case (15WX), the void was caused by an obstruction in the cavity. The existing foil vapor barrier was torn and crumpled near the top of the cavity and prevented the insulation from completely filling the cavity. In the other 3 homes, no physical barrier was evident.

The fact that insulation voids occurred in certain cavities while adjacent cavities were completely filled raises speculation that the cavity may not have contained sufficient material to completely fill or to maintain complete fill of the cavity after settled density (Ref. 2) had occurred. Observations of the densities measured in the loose-fill cellulose sidewalls are of interest in this regard. House 23 had a grand total of 3 openings made in its sidewalls: 1 during Phase I, near the bottom of a cavity, and 1 near the top and bottom of a different cavity containing a void during Phase II. The densities of the 2 bottom openings were 3.7 and $3.8 \mathrm{lbs} / \mathrm{cf}$, while the density of the material removed just below the void near the top was $2.71 \mathrm{bs} / \mathrm{cf}$. In House 27,2 openings were made; 1 near the bottom of a cavity during Phase I and 1 near the top of a dif'erent cavity containing a void during Phase II. The density of the lower opening was $3.8 \mathrm{lbs} / \mathrm{cf}$, while the density of the sample taken from the top of the cavity with the void was $3.0 \mathrm{lbs} / \mathrm{cf}$. Two openings were also made in House 15; 1 near the bottom of a cavity during Phase I and 1 near the top of a 
different cavity containing a void during Phase II. The density of the lower cavity was $3.9 \mathrm{lbs} / \mathrm{cf}$, while the density at the top of the cavity containing the void was $2.7 \mathrm{lbs} / \mathrm{cf}$. It must be remembered that this cavity had some physical blockage near the top of the cavity.

The densities of the materials at the top of the rock/slag wool cavities ( $6 \mathrm{WX} 1$, 6WX2) during Phase II exhibited an unusual pattern. The density of the material at the top of the cavity containing the void was $7.6 \mathrm{lbs} / \mathrm{cf}$, while the density at the top of the adjacent full cavity was $4.3 \mathrm{lbs} / \mathrm{cf}$.

The density range of the cellulose material at the top of the void cavities compared with the density of the material found lower in the cavity raises the speculation that installation, coupled with a tendency of the insulating material to naturally reach a settled density, could be responsible for the voids at the top of the observed cavities. If insufficient material was installed in the cavity to assure a density range of $+-2.7-3.01 \mathrm{bs} / \mathrm{cf}$ at the top of the cavity and +- $3.8 \mathrm{lbs} / \mathrm{cf}$ at the bottom of the cavity, the material might naturally settle to such a state over time. On the other hand, installation of sufficient material in the cavity to compensate for this effect may alleviate any tendency for voids to occur at the top of the cavity. 


\subsection{FUEL CONSUMPTION}

The actual effectiveness of retrofit insulation on fuel consumption has recently been questioned (Ref. 4). Phase II of this project collected actual fuel consumption data on a number of residences whose retrofit insulations had been tested.

The fuel consumption records of 19 homes were analyzed. Where possible, monthly fuel consumption data for each residence was collected for 1-2 years before and after the retrofit date. The data was corrected for degree day and fuel Btu content for the major heating months of the year (November, December, January, February, March) and the average consumption per season was compared before and after the retrofit. Table 7 indicates the percent change in consumption before retrofitting to after retrofitting for the 19 homes divided between the various insulation retrofits. Change in fuel consumption ranged from a reduction of $49.9 \%$ to an increase of $30.4 \%$, with an average reduction in fuel consumption of $15 \%$ after reinsulating.

The analysis does not account for a wide variety of factors that may influence fuel consumption in an individual residence, especially the lifestyle of the occupants and other measures they may have taken (weatherstripping, caulking, etc.) to reduce their energy use. It nonetheless indicates a positive correlation between reinsulation and a reduction in fuel use. 


\subsection{DENSITY AND THERMAL RESISTANCE RETESTS}

The density values of glass fiber attic samples reported in the Phase I report were questioned by members of the insulation industry as being incorrect. Eight samples of loose-fill glass fiber were remeasured for density and thermal resistance in Spring, 1979. The samples were randomly selected from the data base established in Phase I. The results can be found in Table 8 . Field and laboratory procedures were the same as Phase I except that density was calculated in the field as well as in the laboratory. Laboratory procedures can be found in Appendix 1. In all cases, an attempt was made to take the Phase II sample as close as possible to the location of the Phase I sample.

In every case, the Phase II results, as indicated in Table 8 , differ considerably from the Phase I results. Whereas the in situ density reported during Phase I were considerably higher than would have normally been expected for loose-fill glass fiber materials, the Phase II measured densities were considerably lower and generally, in line with expected valueo. Phase I field and laboratory procedures were carefully scrutinized for possible error in measurement and identification. No explanation could be found for the great difference between Phase I and II. Beoause of the errors diocovered, 21 references to in situ density, and thus, thermal resistance, of $1003 e-f i l l$ glass fiber attic insulations should be deleted from thē Fhase I repurt. The Phase II results contained in Table 8 should be used in lieu of all reported density and thermal resistance figures for loose-fill glass fiber ceiling samples in the Phase I report. 


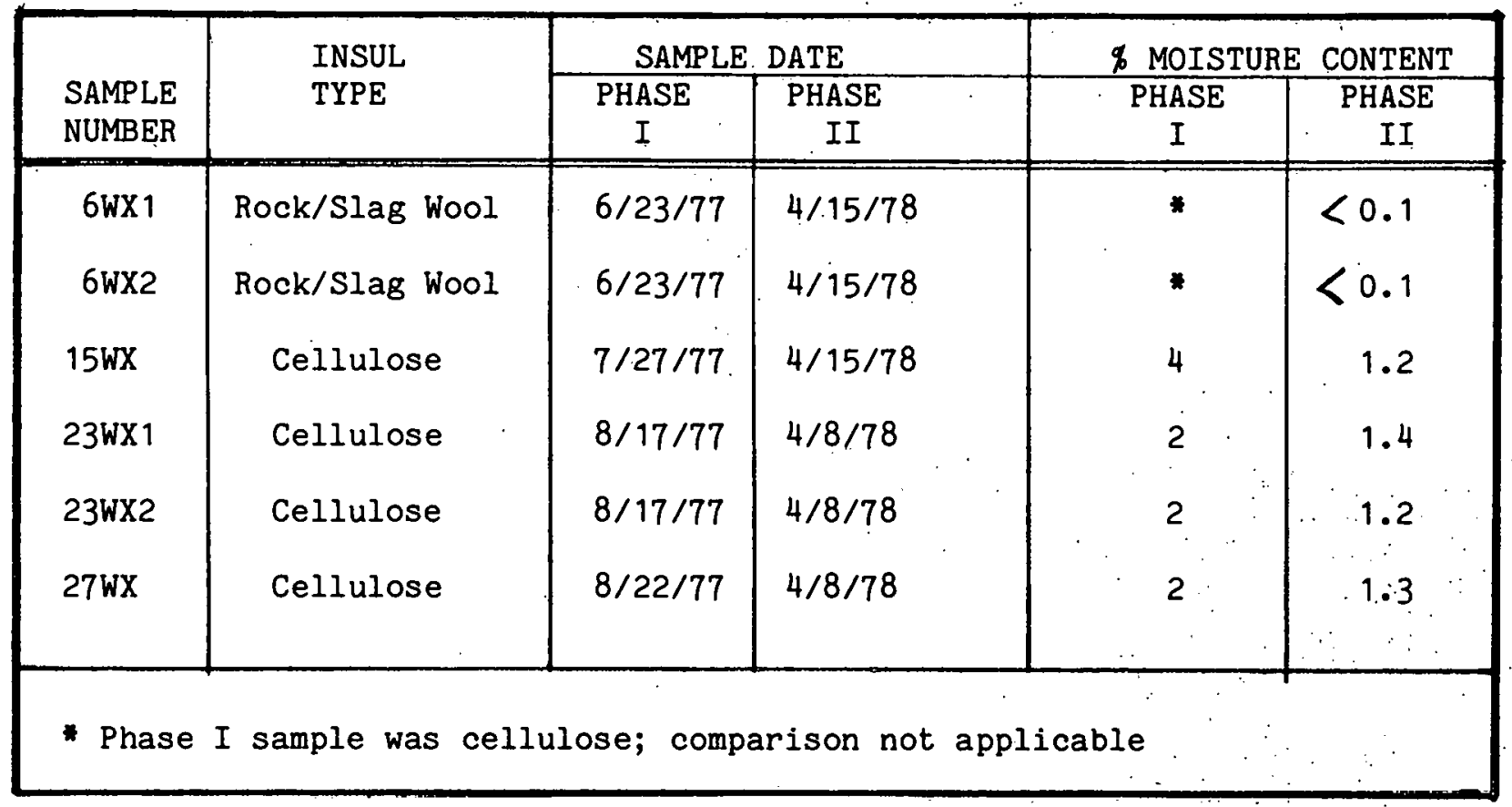

TABLE 1 PHASE I AND II SIDEWALL MOISTURE CONTENT RESULTS AND OBSERVATIONS 


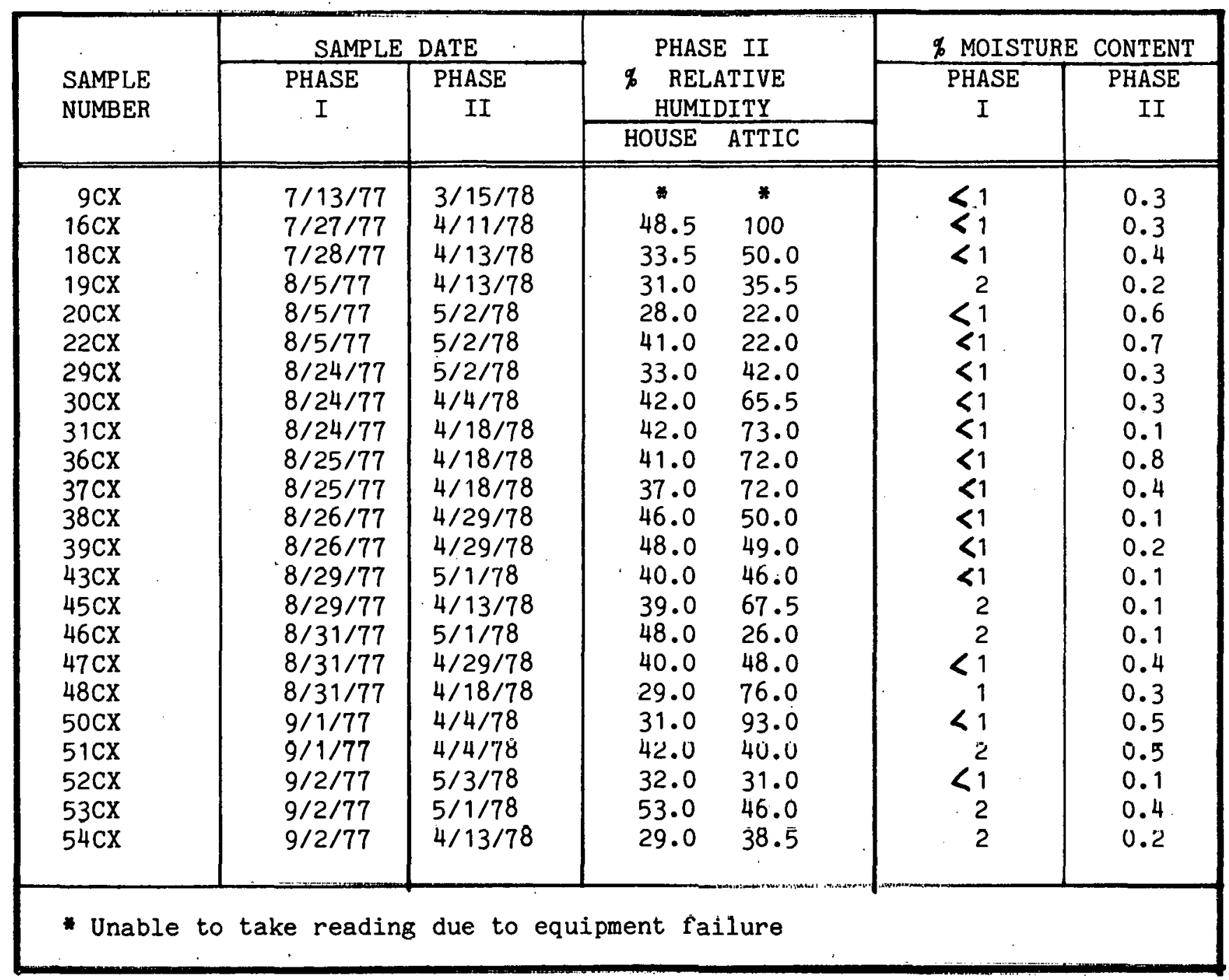

TABLE 2 PHASE I AND II LOOSE-FILL GLASS FIBER MOISTURE CONTENT RESULTS AND OBSERVATIONS 


\begin{tabular}{|c|c|c|c|c|c|c|}
\hline \multirow{3}{*}{$\begin{array}{l}\text { SAMPLE } \\
\text { NUMBER }\end{array}$} & \multicolumn{2}{|c|}{ SAMPLE DATE } & \multirow{2}{*}{\multicolumn{2}{|c|}{$\% \begin{array}{c}\text { PHASE II } \\
\text { RELATIVE } \\
\text { HUMIDITY }\end{array}$}} & \multicolumn{2}{|c|}{$\$$ MOISTURE CONTENT } \\
\hline & \multirow[t]{2}{*}{$\begin{array}{c}\text { PHASE } \\
\text { I }\end{array}$} & \multirow[t]{2}{*}{$\begin{array}{c}\text { PHASE } \\
\text { II }\end{array}$} & & & \multirow[t]{2}{*}{$\begin{array}{c}\text { PHASE } \\
\text { I }\end{array}$} & \multirow[t]{2}{*}{$\begin{array}{c}\text { PHASE } \\
\text { II }\end{array}$} \\
\hline & & & HOUSE & ATTIC & & \\
\hline $\begin{array}{r}1 \mathrm{CX} \\
11 \mathrm{CX} \\
12 \mathrm{CX} \\
13 \mathrm{CX} \\
17 \mathrm{CX} \\
21 \mathrm{CX} \\
23 \mathrm{CX} \\
26 \mathrm{CX} \\
27 \mathrm{CX} \\
33 \mathrm{CX} \\
34 \mathrm{CX} \\
44 \mathrm{CX} \\
49 \mathrm{CX} \\
55 \mathrm{CX}\end{array}$ & $\begin{array}{l}6 / 9 / 77 \\
7 / 14 / 77 \\
7 / 26 / 77 \\
7 / 26 / 77 \\
7 / 28 / 77 \\
8 / 5 / 77 \\
8 / 17 / 77 \\
8 / 22 / 77 \\
8 / 22 / 77 \\
8 / 25 / 77 \\
8 / 25 / 77 \\
8 / 29 / 77 \\
8 / 31 / 77 \\
9 / 2 / 77\end{array}$ & $\begin{array}{l}5 / 1 / 78 \\
5 / 1 / 78 \\
4 / 29 / 78 \\
4 / 11 / 78 \\
4 / 13 / 78 \\
4 / 18 / 78 \\
4 / 8 / 78 \\
4 / 8 / 78 \\
4 / 8 / 78 \\
4 / 4 / 78 \\
4 / 18 / 78 \\
4 / 13 / 78 \\
4 / 11 / 78 \\
5 / 2 / 78\end{array}$ & $\begin{array}{l}48.0 \\
39.0 \\
47.0 \\
39.0 \\
41.0 \\
38.0 \\
* \\
27.5 \\
48.0 \\
49.0 \\
39.0 \\
44.5 \\
39.0 \\
25.0\end{array}$ & $\begin{array}{l}31.0 \\
30.0 \\
48.0 \\
52.0 \\
47.0 \\
59.0 \\
46.0 \\
44.0 \\
58.0 \\
79.0 \\
92.0 \\
69.0 \\
49.0 \\
28.0\end{array}$ & $\begin{array}{r}<1 \\
<1 \\
<1 \\
<1 \\
6 \\
5 \\
2 \\
2 \\
2 \\
2 \\
2 \\
<1 \\
5 \\
<1\end{array}$ & $\begin{array}{r}5.3 \\
2.9 \\
4.6 \\
3.7 \\
5.4 \\
11.1 \\
8.9 \\
5.5 \\
8.6 \\
7.1 \\
6.2 \\
6.9 \\
7.6 \\
6.2\end{array}$ \\
\hline
\end{tabular}

TABLE 3 PHASE I AND II LOOSE-FILL CELLULOSE MOISTURE CONTENT RESULTS AND OBSERVATIONS 


\begin{tabular}{|c|c|c|c|c|c|c|}
\hline \multirow{3}{*}{$\begin{array}{l}\text { SAMPLE } \\
\text { NUMBER }\end{array}$} & \multicolumn{2}{|c|}{ SAMPLE DFTE } & \multirow{2}{*}{\multicolumn{2}{|c|}{$\begin{array}{c}\text { PHASE II } \\
\text { RELATIVE } \\
\text { HUMIDITY }\end{array}$}} & \multicolumn{2}{|c|}{ \% MOISTURE CONTENT } \\
\hline & \multirow[t]{2}{*}{$\begin{array}{c}\text { PHASE } \\
\text { I }\end{array}$} & \multirow[t]{2}{*}{$\begin{array}{c}\text { PHE.SE } \\
\text { II }\end{array}$} & & & \multirow[t]{2}{*}{$\begin{array}{c}\text { PHASE } \\
\text { I }\end{array}$} & \multirow[t]{2}{*}{$\begin{array}{c}\text { PHASE } \\
\text { II }\end{array}$} \\
\hline & & & HOUȘE & ATTIC & & \\
\hline $8 \mathrm{CX}$ & $7: / 13 / 7 i$ & $5 / 2 / 78$ & 28.0 & 37.0 & $<1$ & 0.2 \\
\hline $14 C X$ & $7 / 27 / 7 i$ & $4 / 13 / 78$ & 32.0 & 57.0 & 2 & 0.3 \\
\hline $42 c x$ & $8 / 26 / 7^{7}$ & $4 / 13 / 73$ & 39.0 & 51.0 & $<1$ & 0.3 \\
\hline
\end{tabular}

TABLE 4 PHASE I AND III LOOSE-FILL, ROCK/SLÄG WOOL MOISTURE CONTENT RESULTS AND OBSERVATIONS 


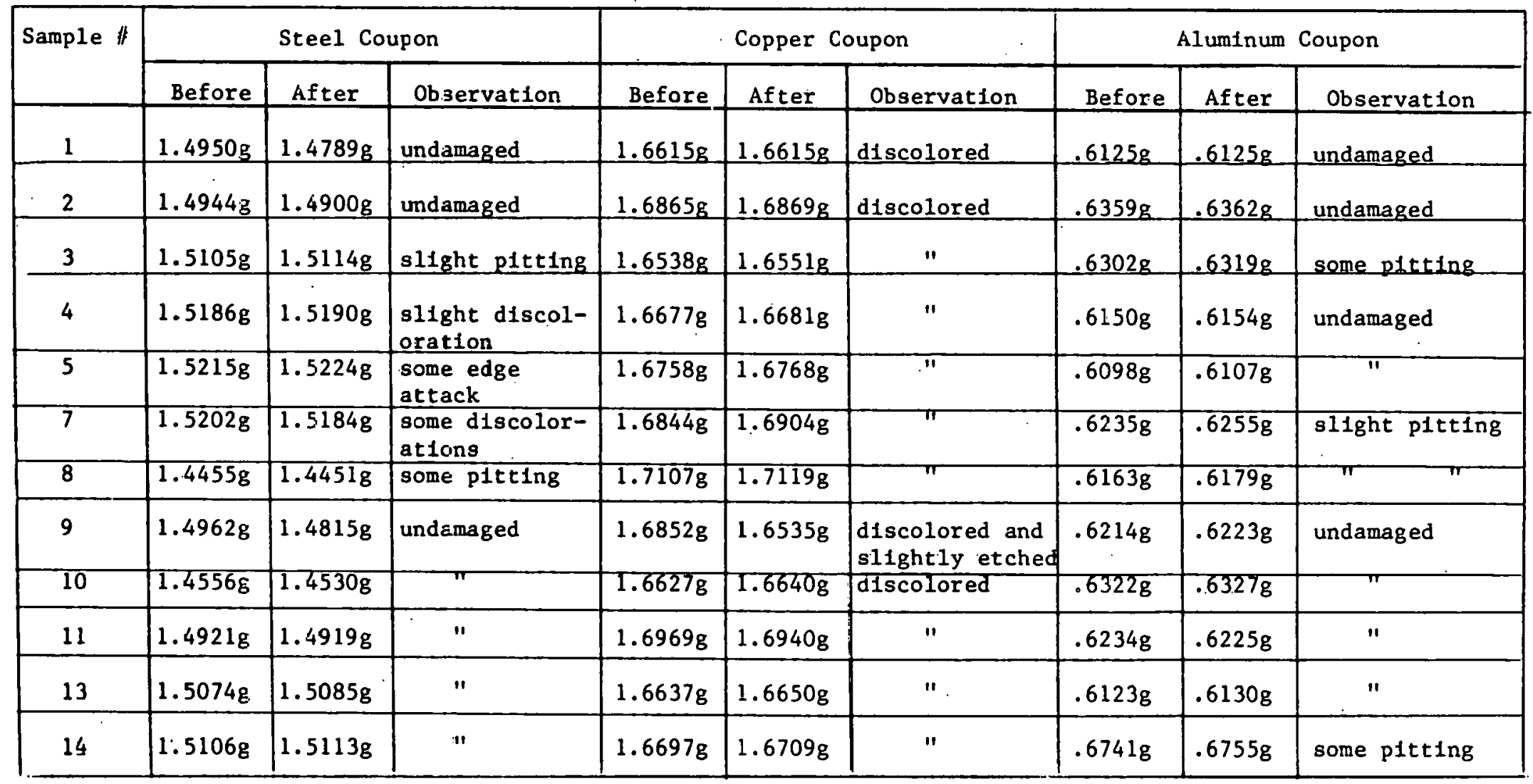

TABLE 5 SURYARY OF LABORATORY WEIGHTS AND OBSERVATIONS OF CORROSION

COUPONS 


\begin{tabular}{|c|c|c|c|c|}
\hline $\begin{array}{l}\text { SAMPLE } \\
\text { NUMBER }\end{array}$ & $\begin{array}{l}\text { • } \\
\text { INSULATION } \\
\text { TYPE }\end{array}$ & $\begin{array}{c}\text { AGE } \\
\text { YEARS } \\
\text { PHASE II } \\
\end{array}$ & $\begin{array}{l}\text { DENSITY } \\
\text { PHASE } \\
\quad \text { I } \\
\end{array}$ & $\begin{array}{c}\text { PHASE } \\
\text { II } \\
\end{array}$ \\
\hline $6 W X:$ & Rock!Slag Wool & $12+$ & $\star$ & 4.3 \\
\hline $6 W \times 2$ & Rock!'Slag Wool & $12+$ & * & 7.6 \\
\hline $15 \mathrm{WX}$ & Cell-ilose & 2.75 & 3.9 & 2.7 \\
\hline 23WX.1 & Cellulose & 2.10 & 3.8 & 2.9 \\
\hline $23 W \times 2$ & Cellulose & 2.10 & 3.8 & 3.7 \\
\hline $27 W X$ & Cellulose & 1.75 & 3.8 & 3.0 \\
\hline
\end{tabular}

TABLE 6 PHASE I AND II SIDEWALL DEWSITY RESULTS 


\begin{tabular}{|c|c|c|}
\hline $\begin{array}{l}\text { DESCRIPTION OF RETROFIT } \\
\text { INSULATION }\end{array}$ & $\begin{array}{l}\text { SAMPLE } \\
\text { NUMBER }\end{array}$ & $\begin{array}{l}\% \text { CHANGE IN FUEL } \\
\text { CONSUMPTION }\end{array}$ \\
\hline Added to Attic & $\begin{array}{l}21 \\
28 \\
30 \\
32 \\
33 \\
35 \\
36 \\
51 . \\
42\end{array}$ & $\begin{array}{r}-5.6 \\
+5.2 \\
+30.4 \\
-16.5 \\
-22.1 \\
-3.5 \\
-13.6 \\
-5.9 \\
-10.0\end{array}$ \\
\hline AVERAGE & & -4.6 \\
\hline RANGE & & $-22.1-+30.4$ \\
\hline New Attic and Wall & $\begin{array}{r}23 \\
25 \\
26 \\
6\end{array}$ & $\begin{array}{r}-21.3 \\
-10.7 \\
-24.6 \\
+3.6\end{array}$ \\
\hline AVERAGE & . & -13.3 \\
\hline RANGE & & $-24.6-+3.6$ \\
\hline Added to Attic and Wall & $\begin{array}{r}5 \\
9 \\
13\end{array}$ & $\begin{array}{l}-34.1 \\
-39.9 \\
-21.1\end{array}$ \\
\hline AVERAGE & & -31.7 \\
\hline RANGE & & $-39.1--21.1$ \\
\hline New Attic, Added to Wall & 1 & $-10 \cdot 3$ \\
\hline Added to Attic, New Wall & 27 & $-49 \cdot 9$ \\
\hline New Wall & 41 & -34.7 \\
\hline TOTAL AVERAGE & & -15.0 \\
\hline
\end{tabular}

TABLE 7 CHANGE IN FUEL CONSUMPTION AFTER APPLICATION OP RETROPIT INSULATION 


\begin{tabular}{|c|c|c|c|c|c|c|}
\hline \multicolumn{4}{|l|}{ PHASE I } & \multicolumn{3}{|c|}{ PHASE II } \\
\hline $\begin{array}{l}\text { SAMPLE } \\
\text { NUMBER }\end{array}$ & $\begin{array}{c}\text { AGE } \\
\text { YEARS }\end{array}$ & $\begin{array}{l}\text { DENSITY } \\
\text { LBS/CF }\end{array}$ & $\begin{array}{l}\text { R PER INCH } \\
\text { H SF F/BTU }\end{array}$ & $\begin{array}{l}\text { AGE } \\
\text { YEARS }\end{array}$ & $\begin{array}{l}\text { DENSITY } \\
\text { LBS/CF }\end{array}$ & $\begin{array}{ll}\text { R } & \text { PER INCH } \\
\text { H SF } & \text { F/BTU }\end{array}$ \\
\hline $20 \mathrm{C}$ & 3.0 & 2.10 & 3.05 & 5.03 & .76 & 2.25 \\
\hline $\begin{array}{l}35 \mathrm{C} \\
36 \mathrm{C}\end{array}$ & $\begin{array}{l}2.0 \\
1.0\end{array}$ & $\begin{array}{l}2.35 \\
4.20\end{array}$ & $\begin{array}{l}3.00 \\
3.70\end{array}$ & $\begin{array}{l}3.83 \\
2.82\end{array}$ & $\begin{array}{l}.78 \\
.63\end{array}$ & $\begin{array}{l}2.20 \\
2.15^{*} *\end{array}$ \\
\hline $\begin{array}{l}43 C^{*} \\
43 C\end{array}$ & 3.5 & 1.70 & 3.25 & 4.93 & .73 & $\begin{array}{l}1.7 \text { (as rec'd) } \\
2.4 \text { (fluffed) }\end{array}$ \\
\hline 450 & 3.17 & 2.40 & 3.70 & 5.02 & .98 & 2.30 \\
\hline $46 C$ & 2.00 & 1.40 & 3.25 & 3.83 & 1.11 & 2.55 \\
\hline $47 \mathrm{C}$ & 3.00 & 2.30 & 3.45 & 4.82 & 1.85 & 3.15 \\
\hline $50 \mathrm{C}$ & 3.00 & 2.95 & 3.70 & 4.74 & 1.16 & $2: 65$ \\
\hline \multicolumn{7}{|c|}{$\begin{array}{l}\text { * Tested as received and machine-fluffed because of the unusually low } \\
\text { value measured without fluffing } \\
\text { * Sample was machine-fluffed for thermal resistance test in order. } \\
\text { to achieve the removal density }\end{array}$} \\
\hline
\end{tabular}

TABLE 8 LABORATORY PROPERTIES OF LOOSE-FILL GLASS FIBER SAMPLES PHASE I AND PHASE II 
MINNESOTA ENERGY AGENCV

INSULATION TEST WORKS

T

SAMPLE NO. 6 Wall $\mathrm{X}-1$

DATE 15 ADr11 1978

SOURCE OF LEAD

\begin{tabular}{l}
\hline GENERAL \\
$\begin{array}{l}\text { AGE: retrof1t over } 12 \\
\text { HEAT SYSTEM }\end{array}$ \\
\hline
\end{tabular}

FIELD OBSERVATIONS

plan location(s) bedroom-north

framing type $2 \times 4$ stud

venting $\mathrm{n} / \mathrm{a}$

condition of wiring $n / a$

condition of structure good

ORIGINAL: insulation type 0

RETROFIT: insulation type mineral fiber

vapor barrier type 0

retrofit installation procedures/problems made second opening east of first

difficulty of opening/closing sample multiple layers/odd framing-second opening

DRESENCE OF: moisture, corrosion, odor, vermin, fungus none

pack²5g excellent/good friability n/a

REPLACEMENT: insulation fiberglass vapor barrier none

\begin{tabular}{|l|}
\hline FIELD TESTS I 2.67" \\
\hline Insulation thickness see below flame n/a \\
\hline
\end{tabular}

SKETCHES (elevation/plan/section)

(siding, sheathing, building paper, existing insulation, new insulation, insulation thickness(es), vapor barrier(s), ceiling materials, flooring, gables, stops \& firebreaks, ventilation, wiring, paint, installation procedures, general notes)

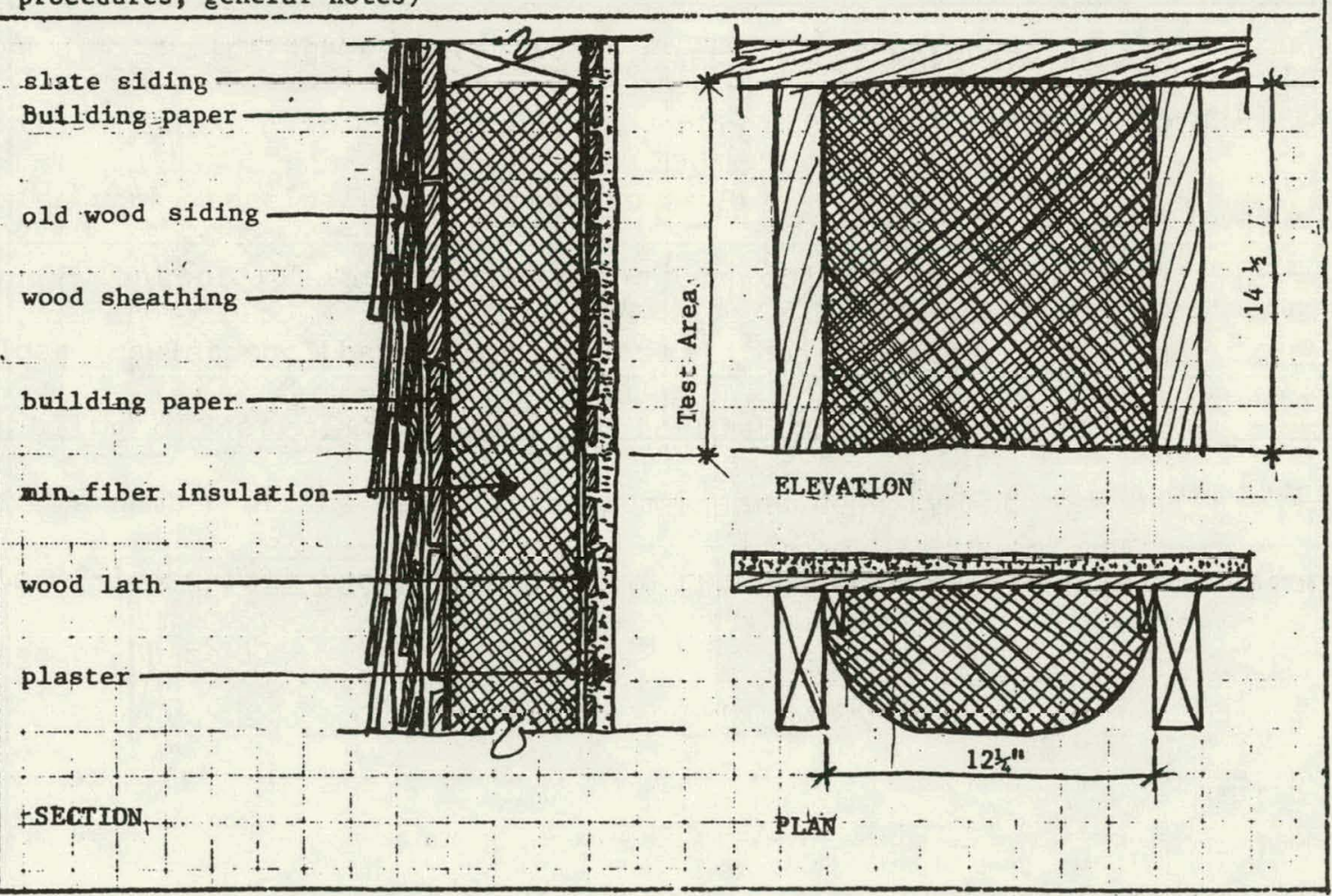

Fig. 1. Field worksheet, sample $6 \mathrm{WX1}$, full cavity. 
MINNESOTA ENERGY AGENCV INSULATION TEST WORKS

SAMPLE NO. 6 Wall X-2

DATE 15 Apr11 1978

SOURCE OF LEAD

GENERAL

AGE: retrofit over 12 house_ ORIENTATION north

HEAT SYSTEM INSTALLER \& DATE unknown

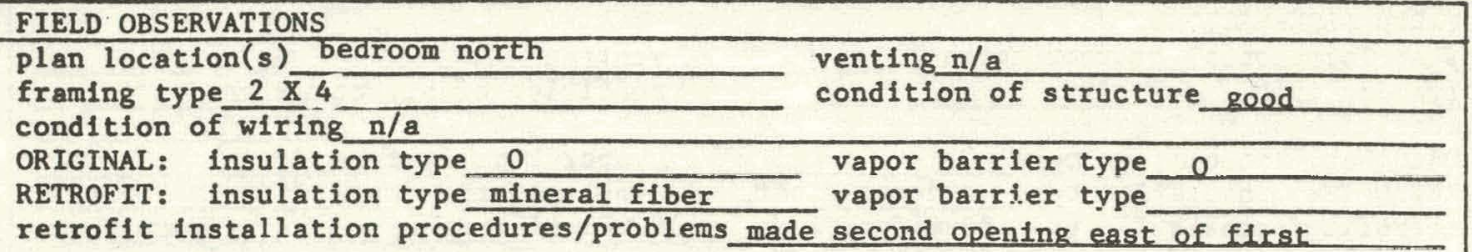

diticulty of opening/closing sample multiple layers/odd framing-second opening

PRESENCE OF: moisture, corrosion, odor, vermin, fungus

none

pack 25 excellent/good friability $n / a$

REPLACEMENT: insulation fiber glass vapor barrier none

\begin{tabular}{|l|}
\hline FIELD TESTS \\
\hline Insulation thickness 2.84" flame n/a \\
\hline
\end{tabular}

SKETCHES (elevation/plan/section)

(siding, sheathing, building paper, existing insulation, new insulation,

insulation thickness(es), vapor barrier(s), ceiling materials, flooring,

gables, stops \& firebreaks, ventilation, wiring, paint, installation procedures, general notes)

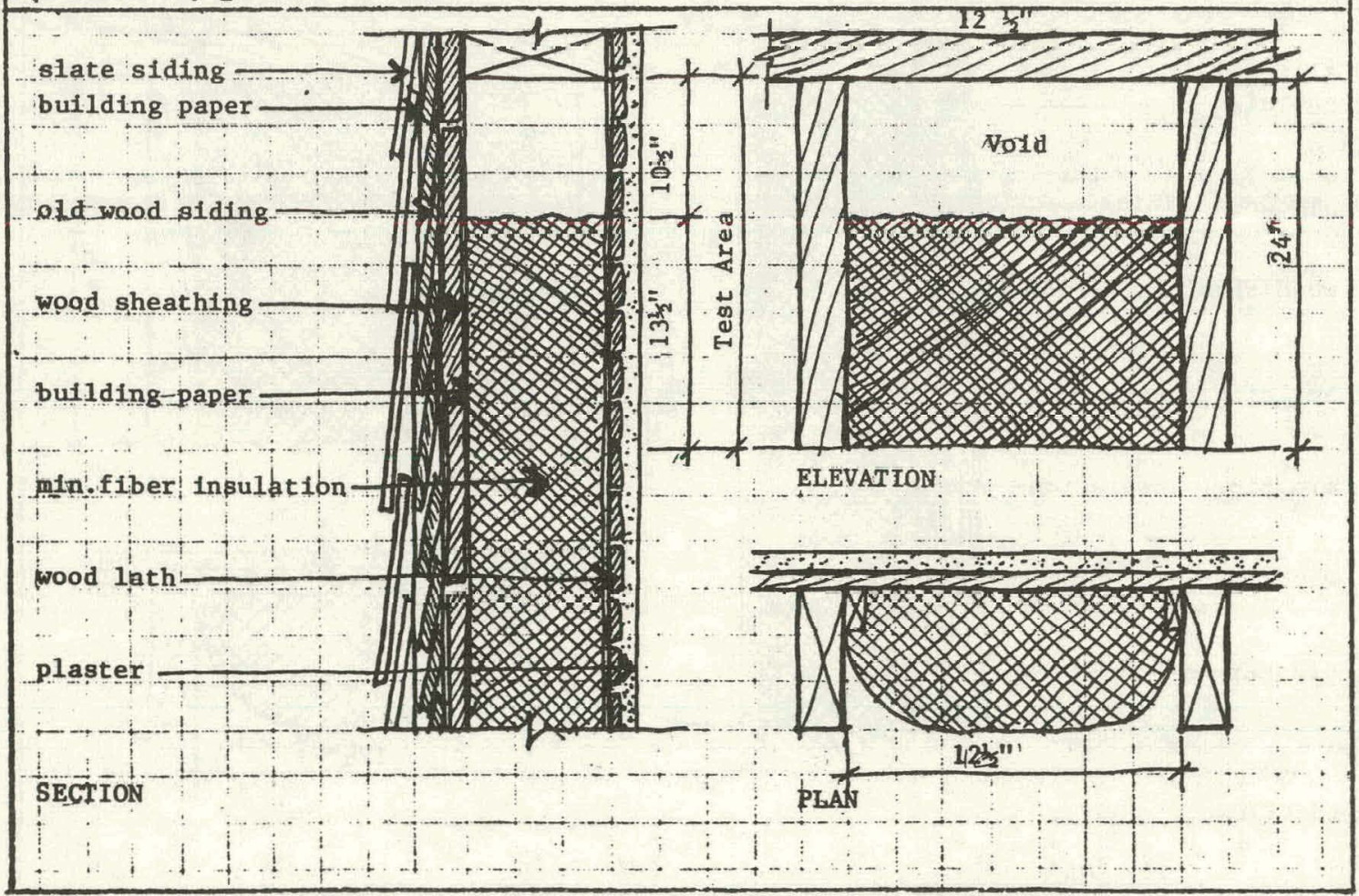

Fig. 2. Field worksheet, samp1e $6 \mathrm{WX} 2$, partial void cavity. 
MINNESOTA ENERGY AGENCV

INSULATION TEST WORKS T

SAMPLE NO. 15 Wa11 X

DATE 15 ADr11 1978

SOURCE OF LEAD

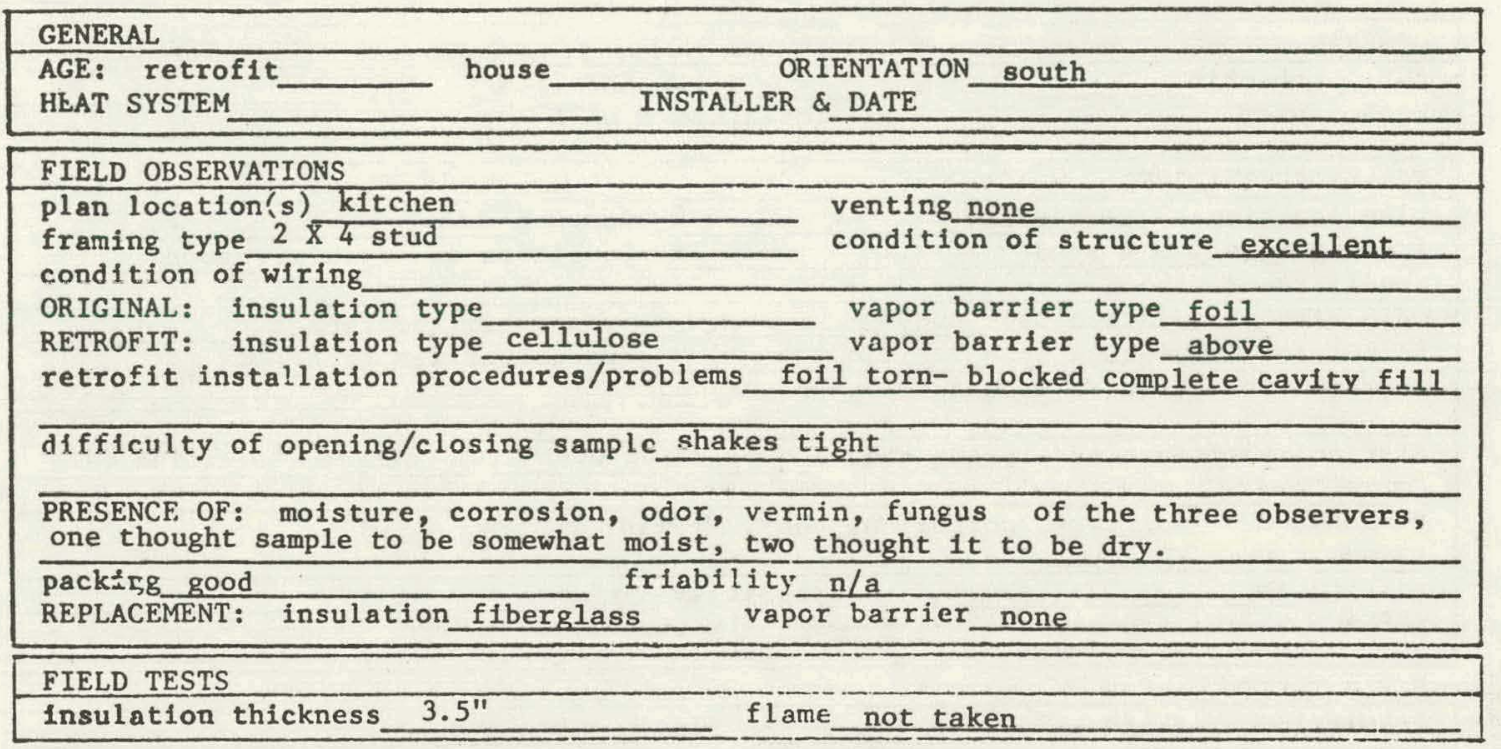

SKETCHES (elevation/plan/section)

(siding, sheathing, building paper, existing insulation, new insulation, insulation thickness(es), vapor barrier(s), ceiling materials, flooring, gables, stops \& firebreaks, ventilation, wiring, paint, installation procedures, general notes)

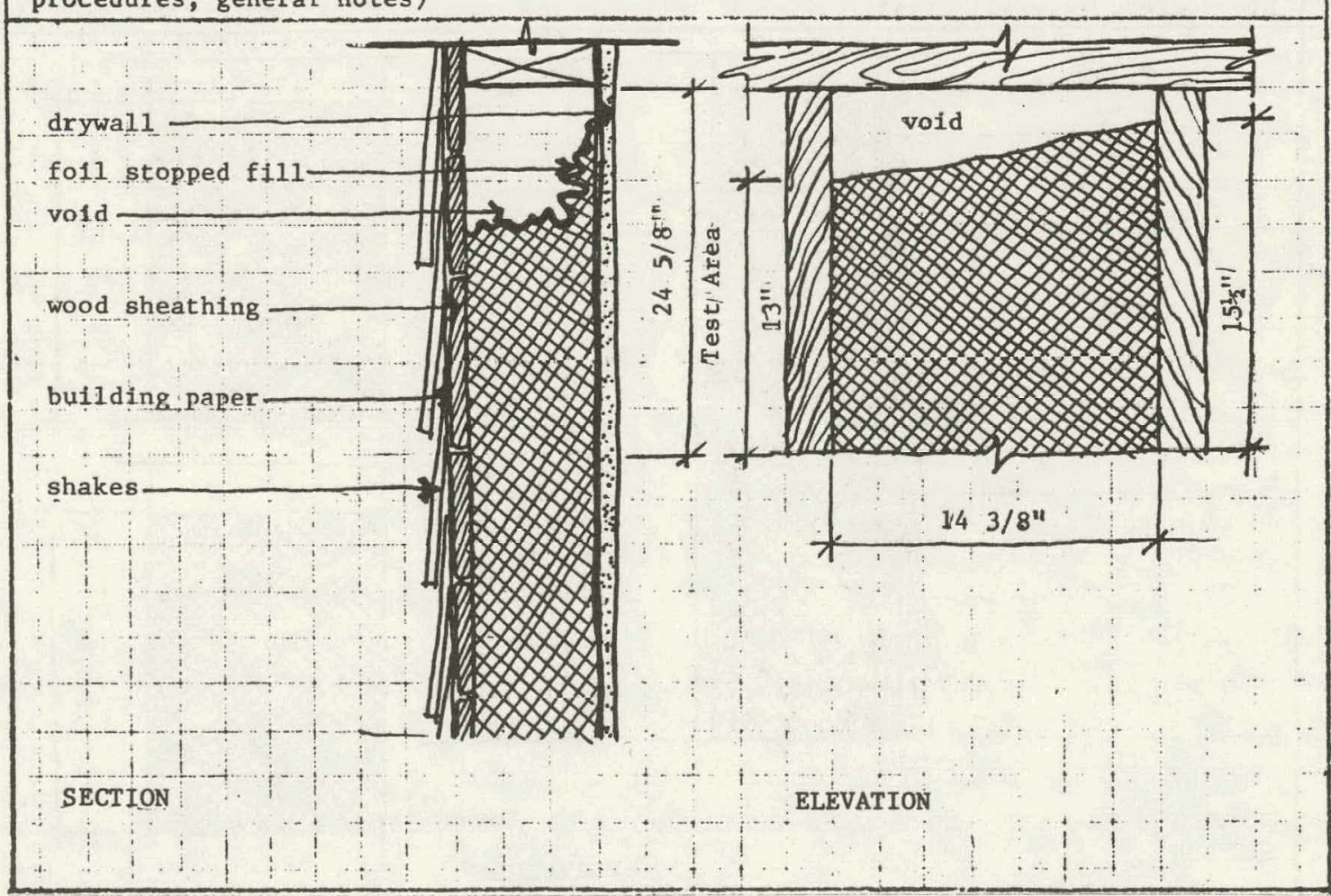

Fig. 3. Field worksheet, sample $15 \mathrm{WX}$, partial vold cavity. 
MINNESOTA ENERGY AGENCV

INSULATION TEST WORKS

$\mathbf{T}$

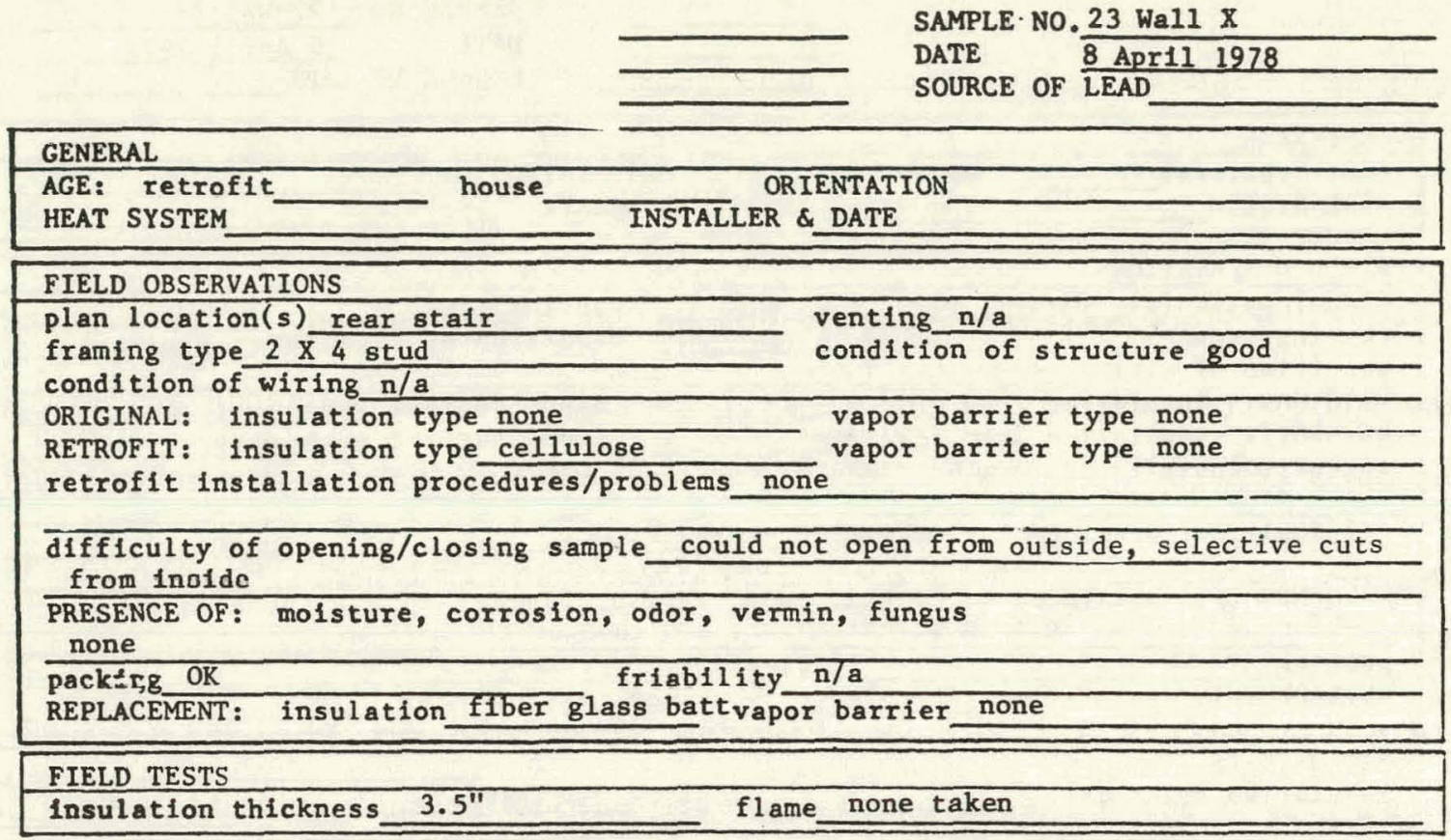

SKETCHES (elevation/plan/section)

(siding, sheathing, bullding paper, existing insulation, new insulation, insulation thickness(es), vapor barrier(s), ceiling materials, flooring, gables, stops \& firebreaks, ventilation, wiring, paint, installation procedures, general notes)

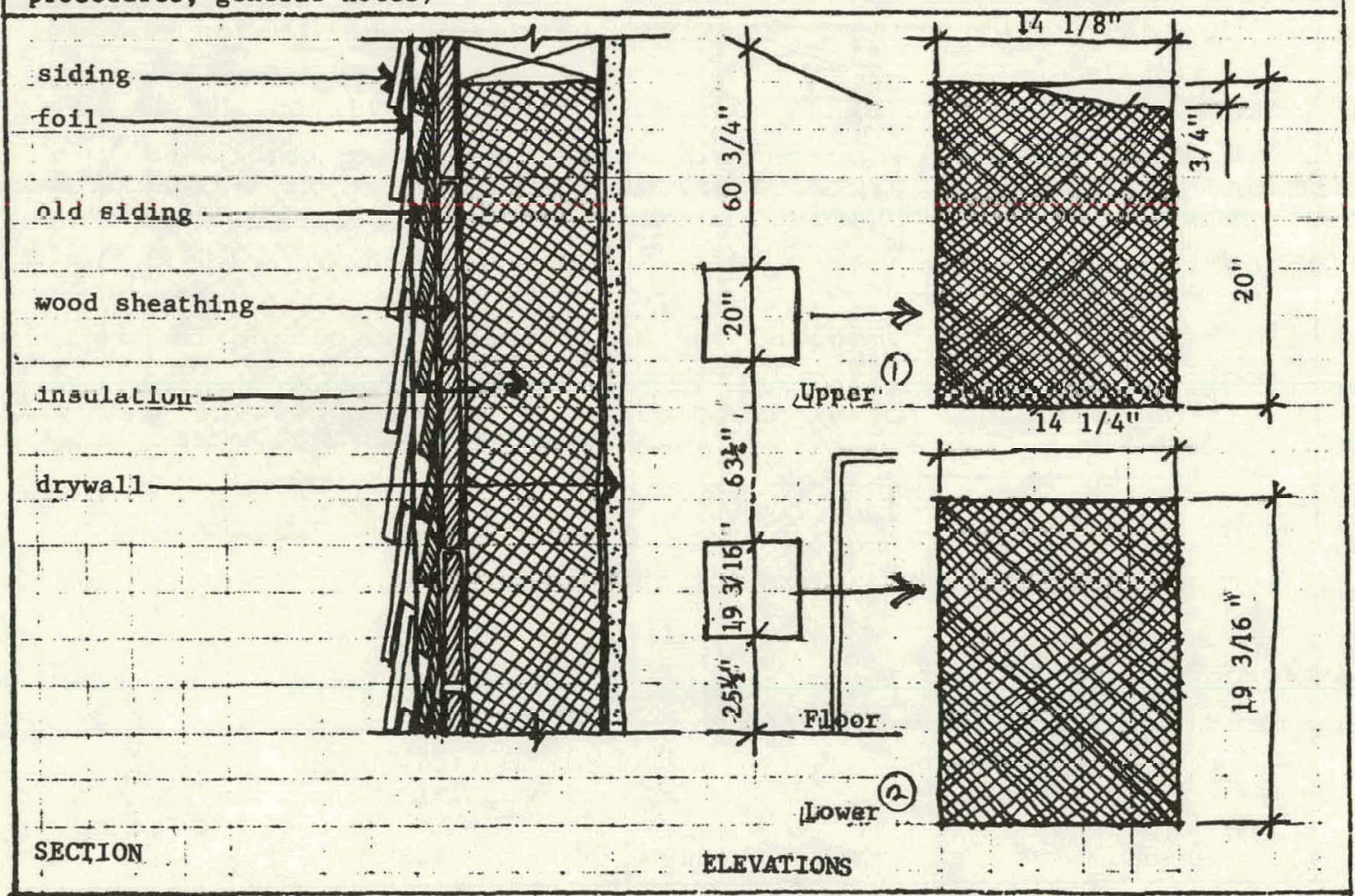

Fig. 4. Field worksheet, sample 23WX, partial void cawity. 
MINNESOTA ENERGY AGENCV INSULATION TEST WORKS

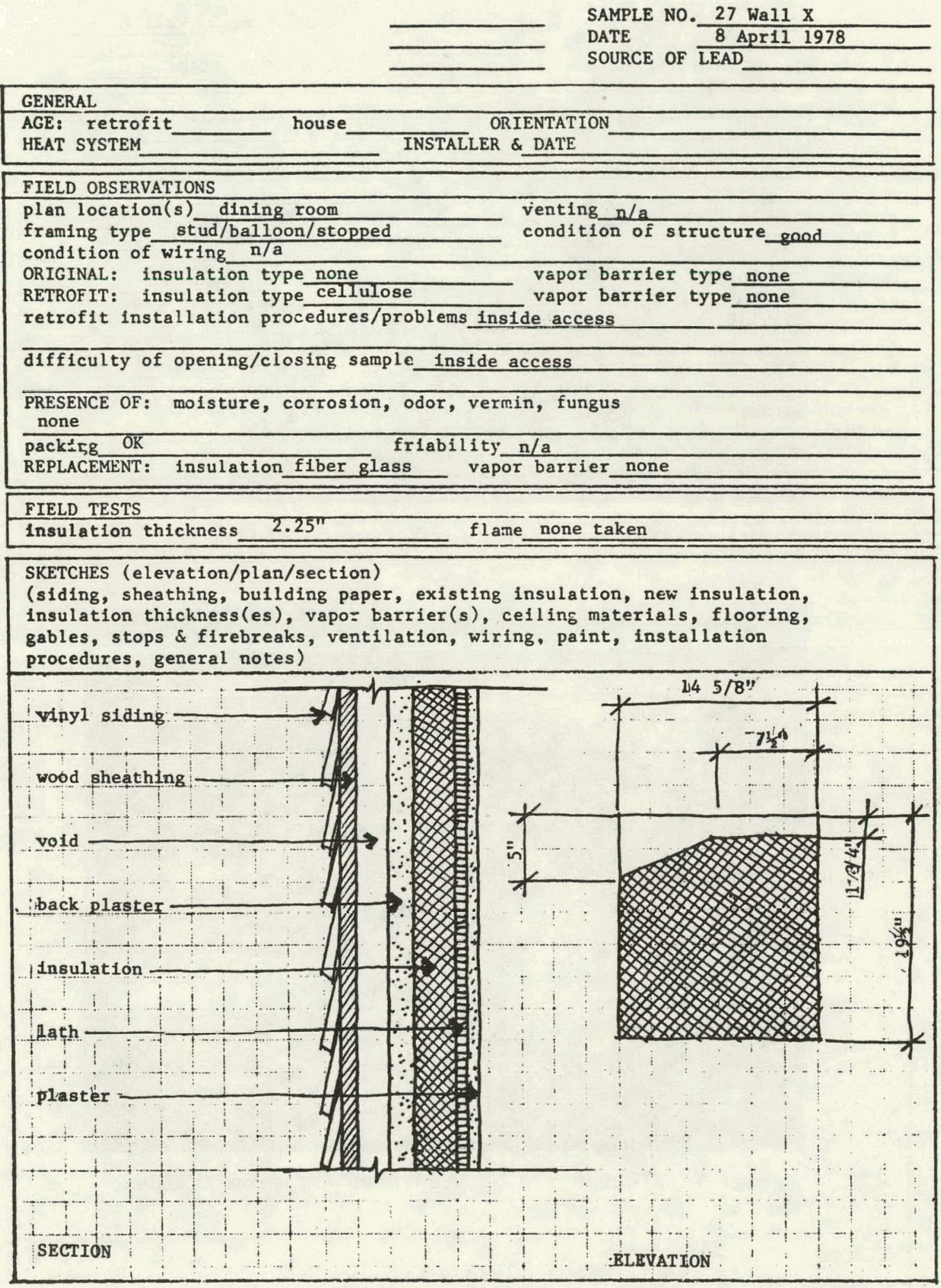

Fig. 5. Field worksheet, sample 27WX, partial vold cavity. 


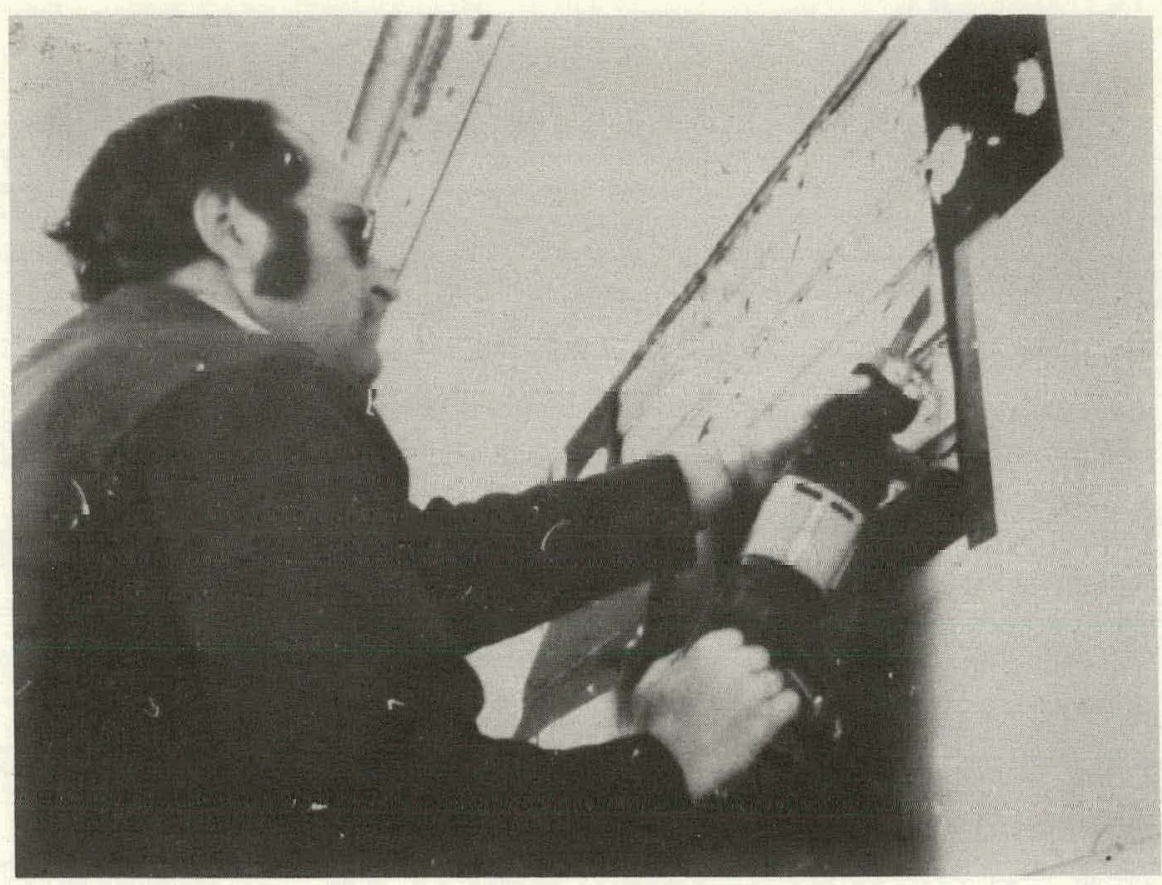

Fig. 6. Opening 6WX from outside.

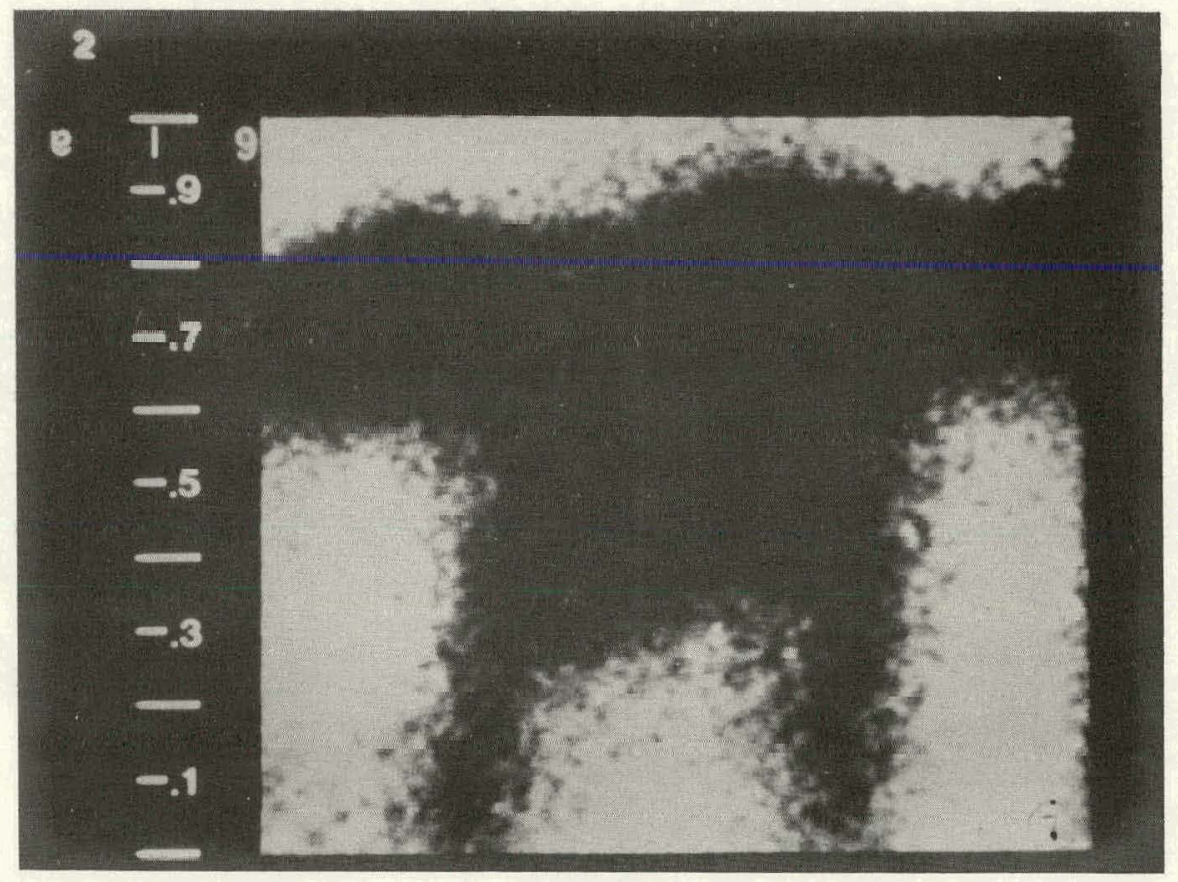

Fig. 7. Thermogram of void area $6 \mathrm{WX}$ from inside. 


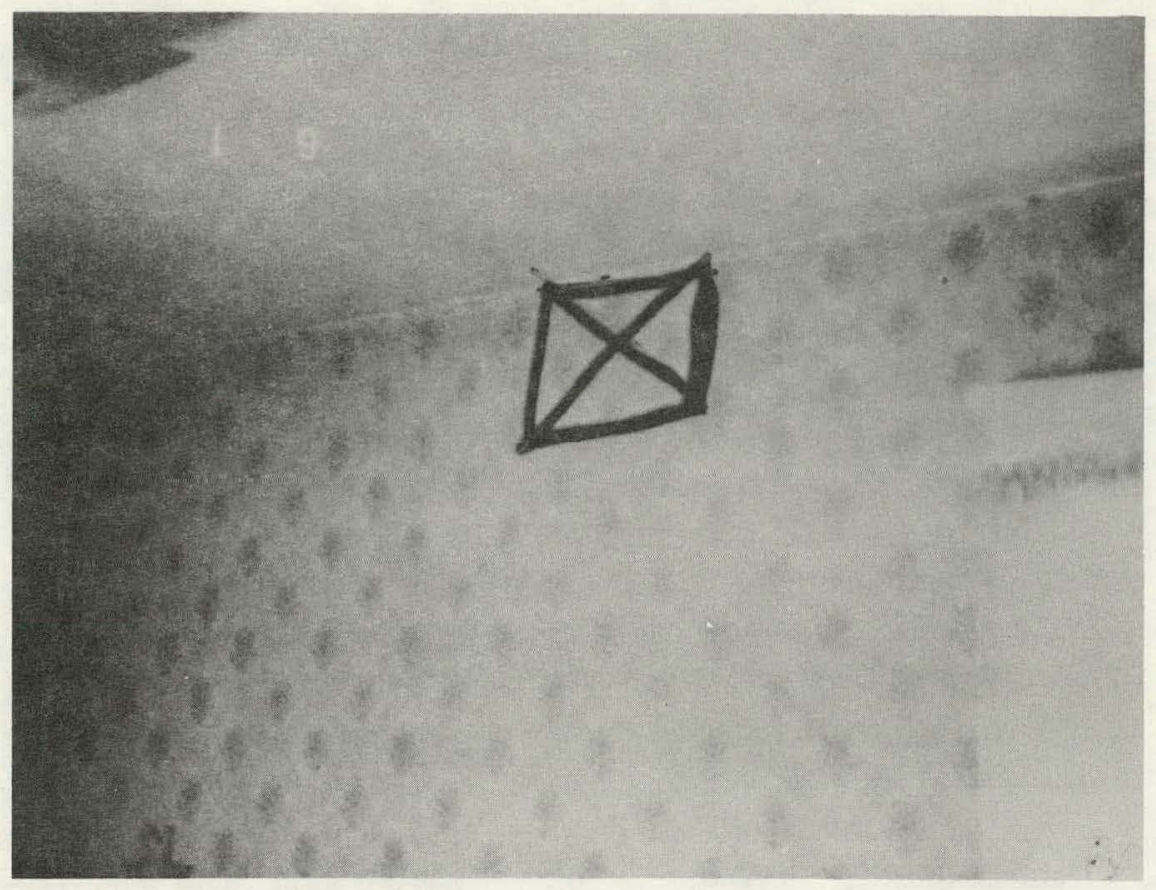

Fig. 8. Photograph of inside $6 \mathrm{WX}$, marking area of void.

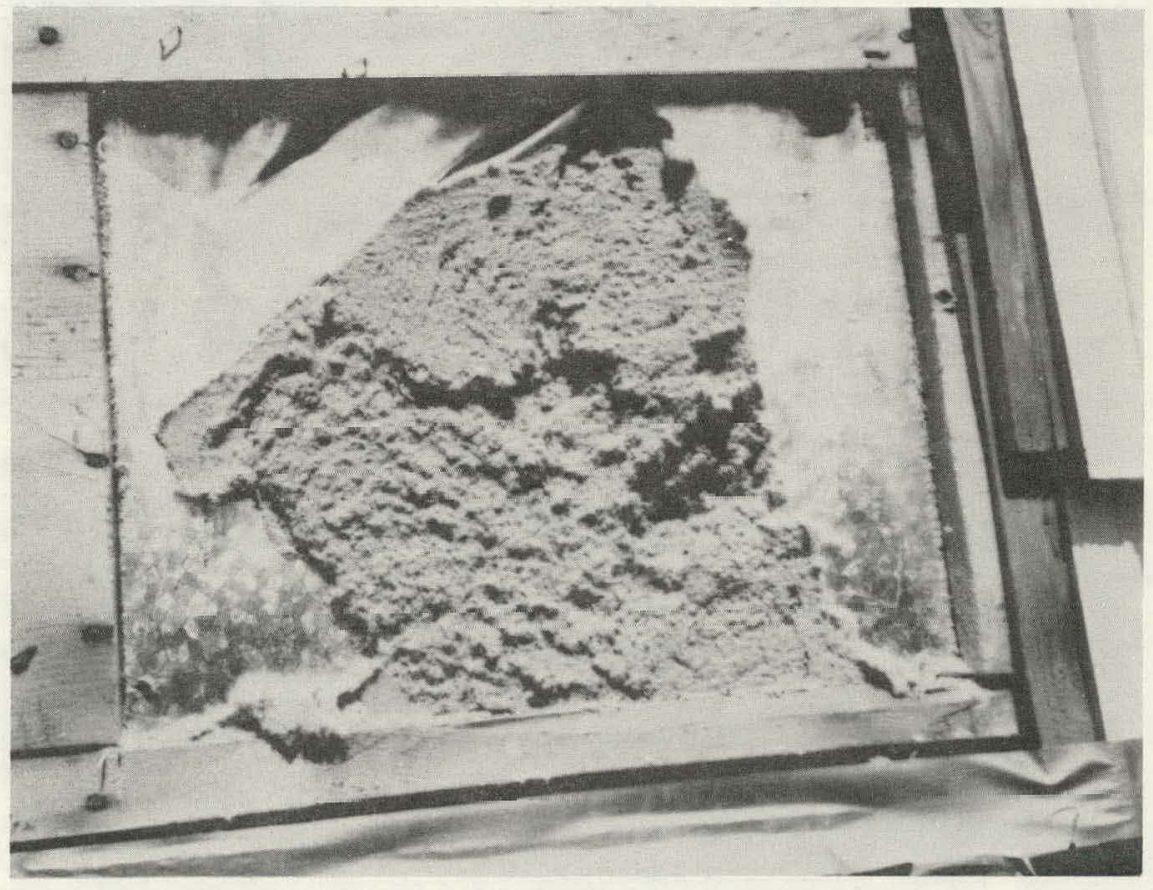

Fig. 9. 15WX opened from outside. 


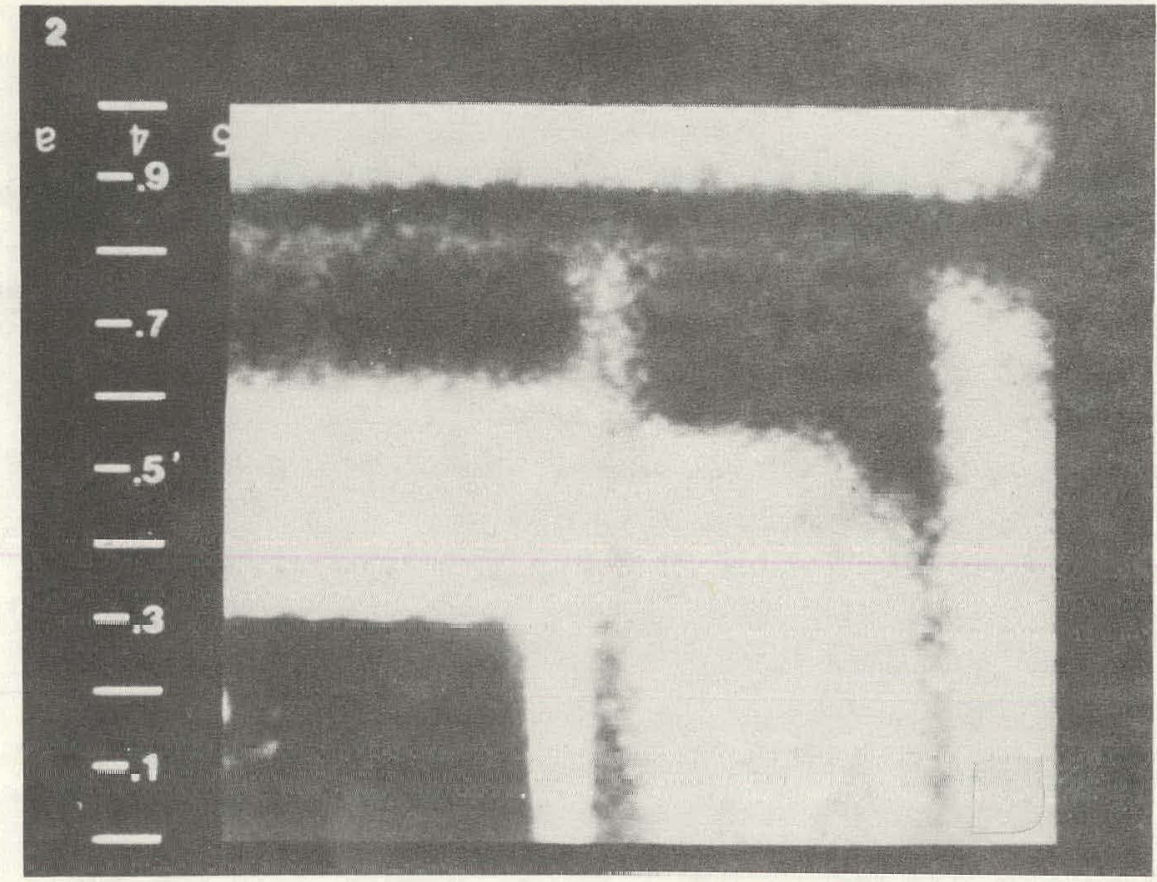

Fig. 10. Thermogram of $15 \mathrm{WX}$ area from inside.

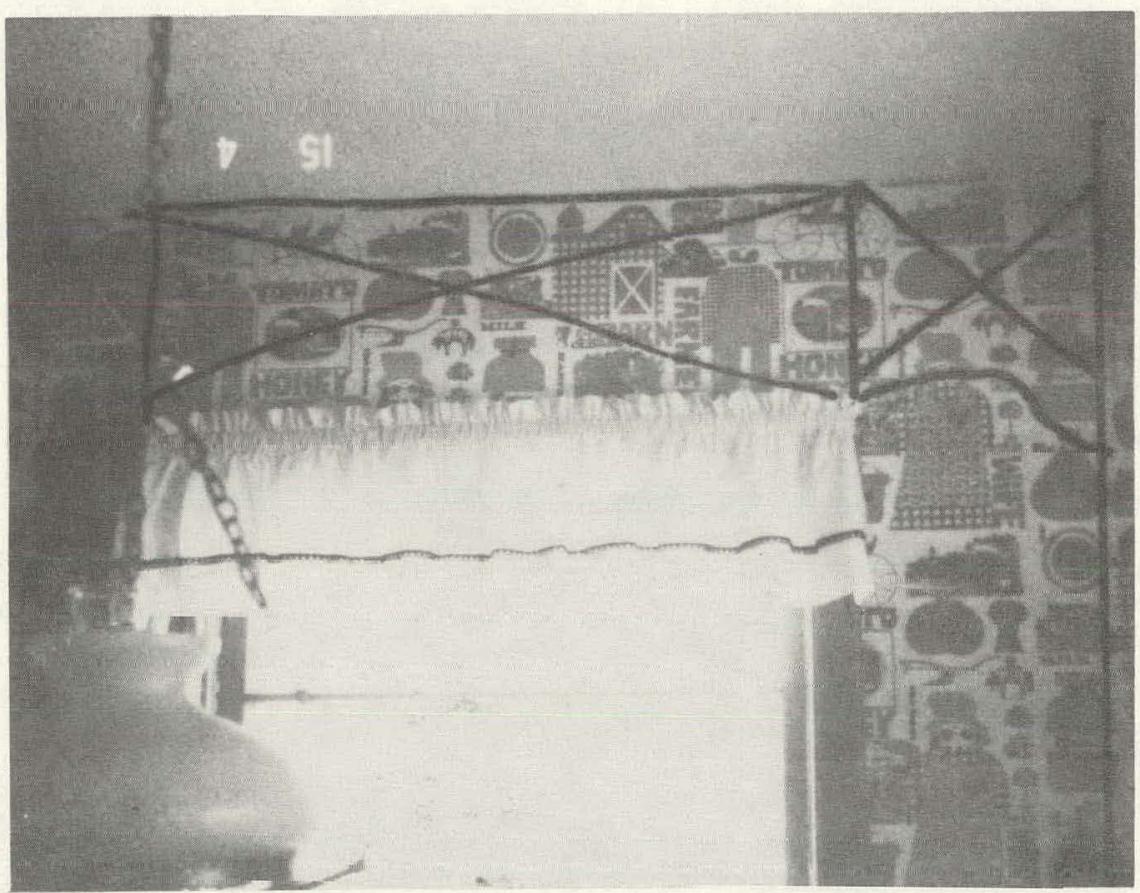

Fig. 11. Photograph of inside $15 \mathrm{WX}$, marking void areas. Area opened was void to upper right of window. 


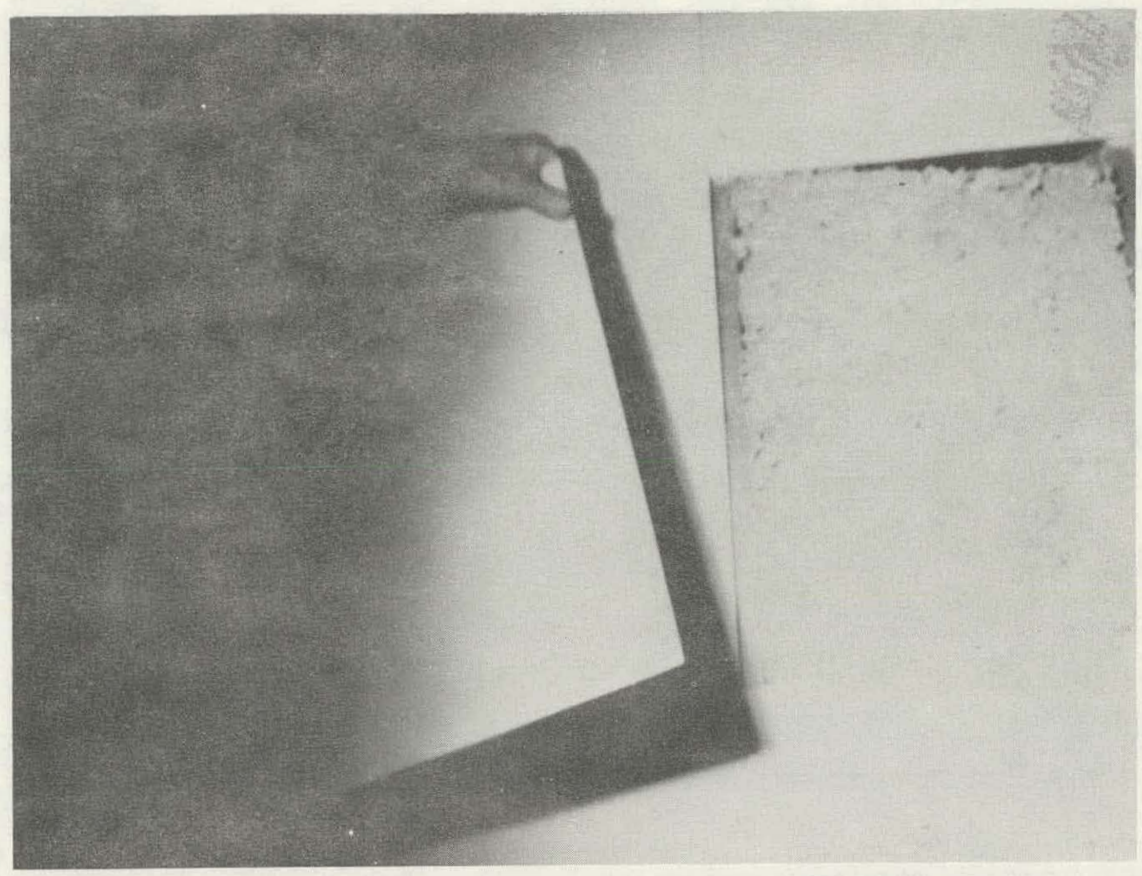

Fig. 12. Top opening from inside 23WX1 showing void.

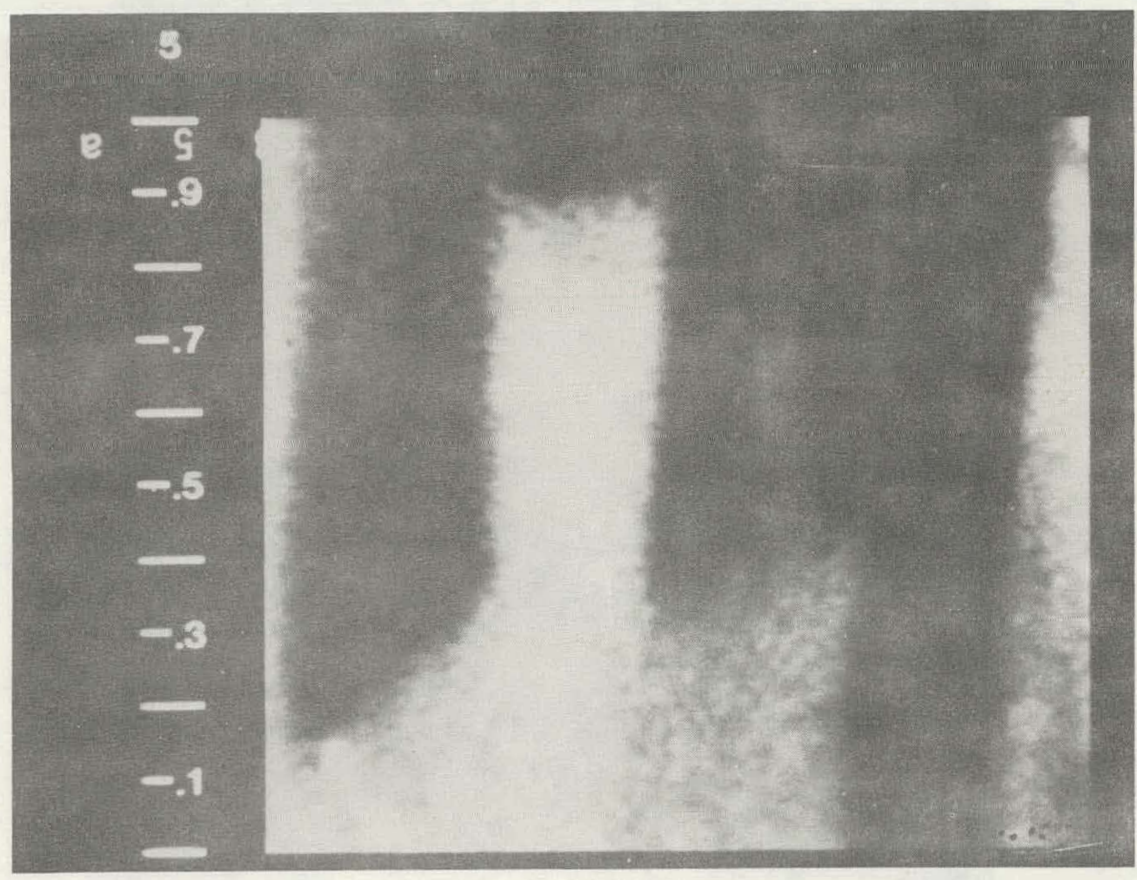

Fig. 13. Thermogram of inside of $23 \mathrm{WX}$ area showing numerous voids. 


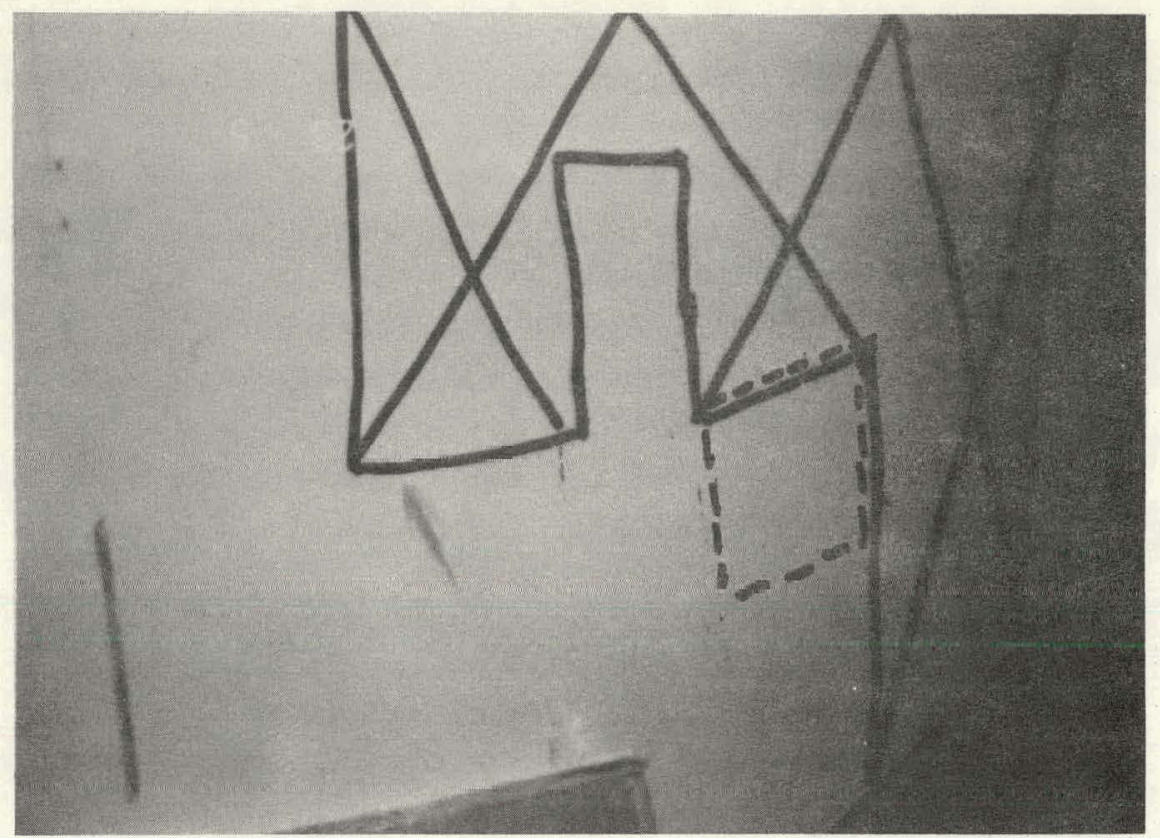

Fig. 14. Photograph of inside of 23WX marking void areas. Dotted line shows approximate location of 23WX1 opening.

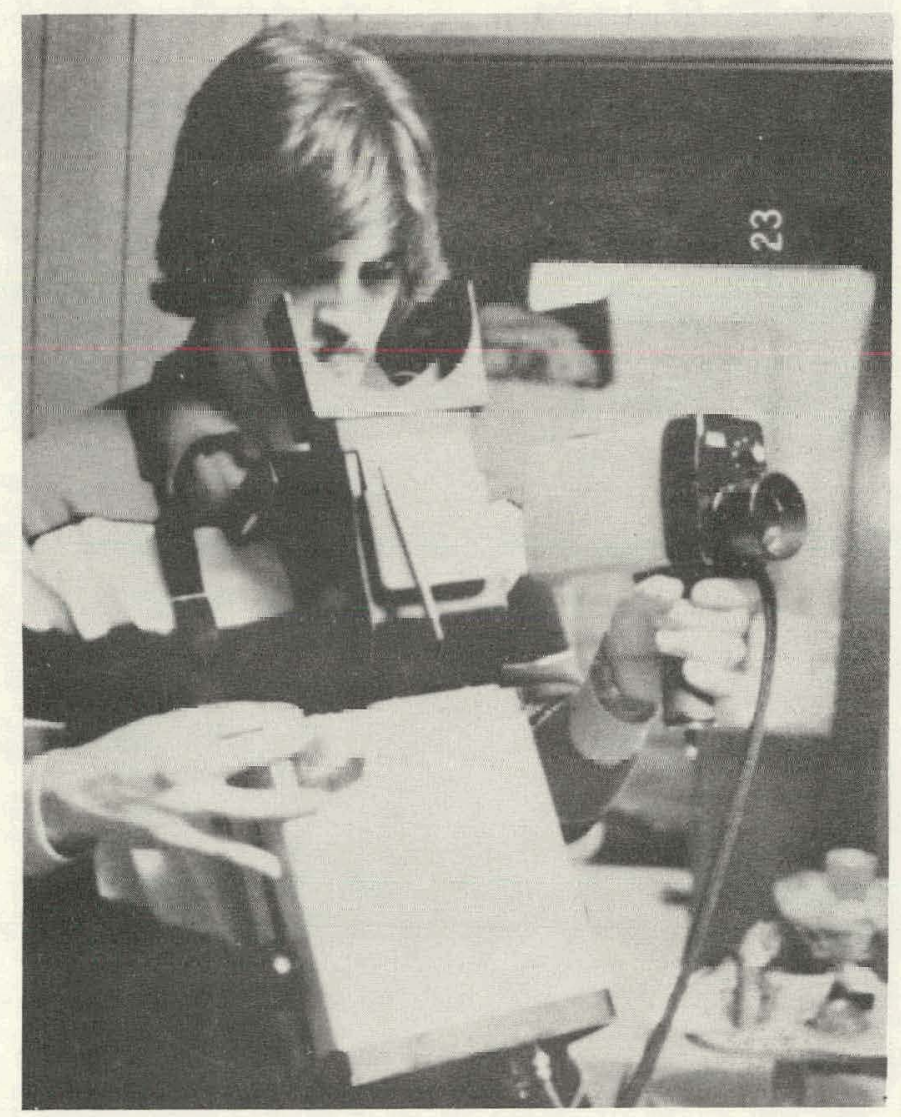

Fig. 15. Thermography equipment. 


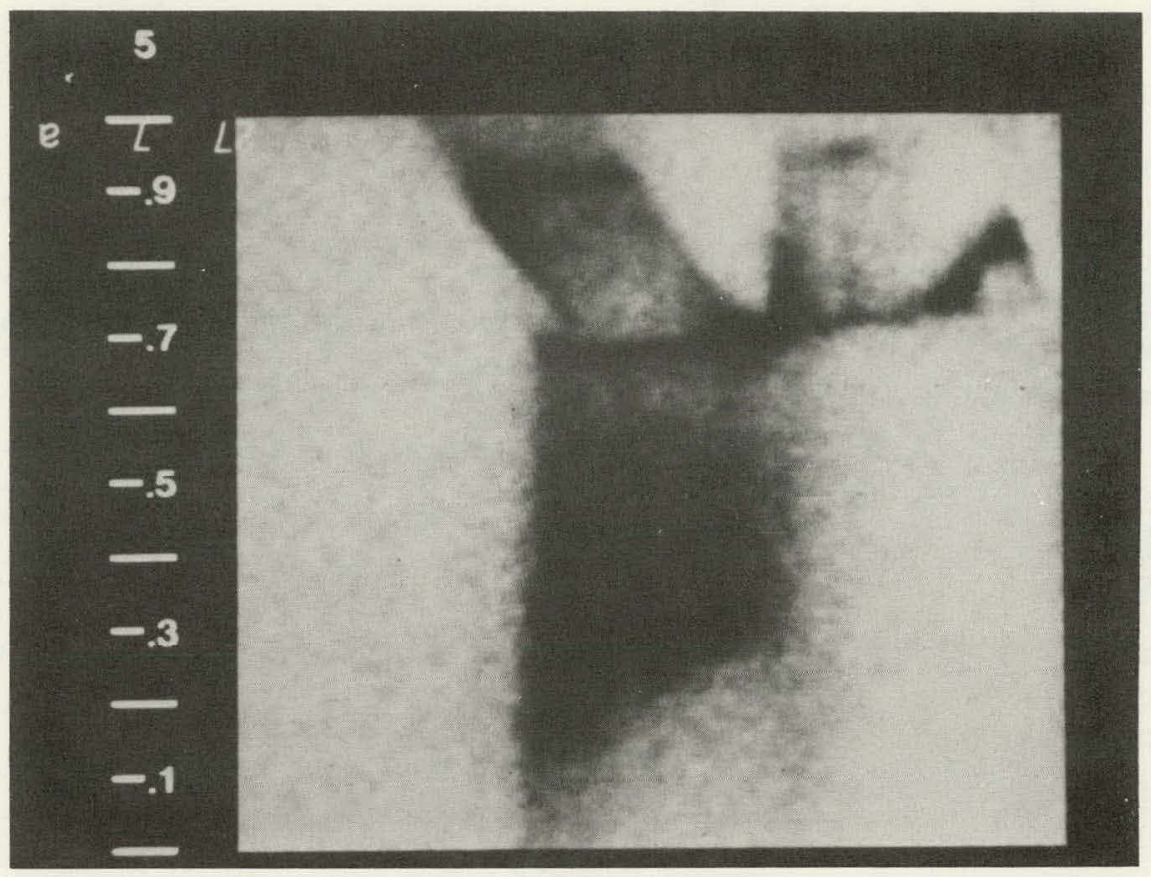

Fig. 16. Thermogram of inside of $27 \mathrm{WX}$ showing voids.

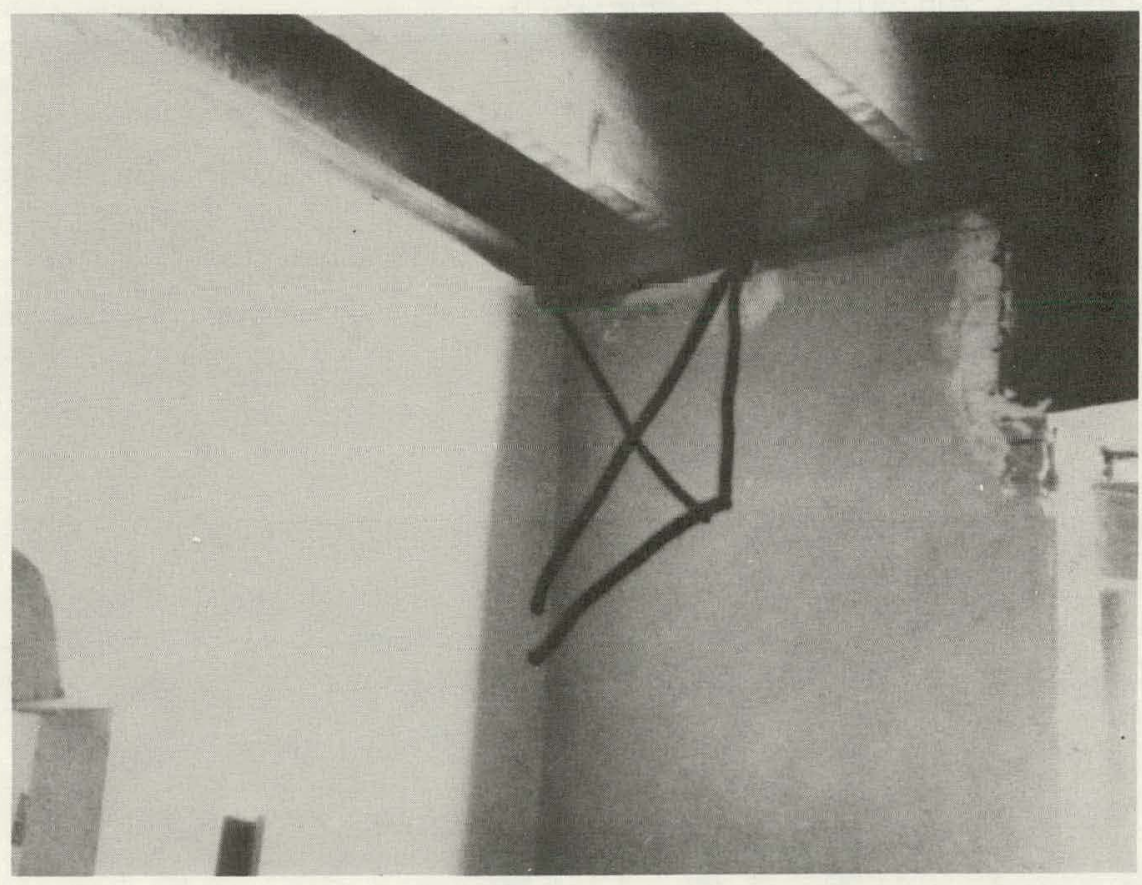

Fig. 17. Photograph of inside of $27 \mathrm{WX}$ marking void area. 


\section{REFERENCES}

1. USDA Forest Service Research Paper, FPL 132, "Condensation Problems: Their Prevention and Solution", 1972.

2. D. M. Burch; C. I. Siu; and F. J. Powell, "Comparison of the Thermal Performance of Three Insulating Materials Commonly Used to Retrofit Exterior Frame Walls in Existing Residences", September 1976.

3. Brookhaven National Laboratory with the Assistance of Dynatech R/D Company, "An Assessment of Thermal Insulation Materials and Systems for Building Applications", June 1978.

4. Dr. Jay McGrew, "Is Your Insulation What It Shouldn't Be?", Home Energy Digest - Wood Burning Quarterly, Summer, 1918. 
APPENDIX 1

\section{LABORATORY EXPERIMENTAL PROCEDURES}

\section{Density}

The density of the loose-fill materials, both cellulose and mineral fiber, were determined from the volume of the sample measured and recorded during sample removal. A cross-sectional area of either wall or ceiling was marked off and measured. The average thickness of the area was then determined by a depth gauge. The sample was placed in double polyethylene bags and sent to a commercial testing laboratory. At the laboratory, the sample material was weighed and the density calculated from the mass and the volume given by the in situ recorded length, width and depth as shown below:

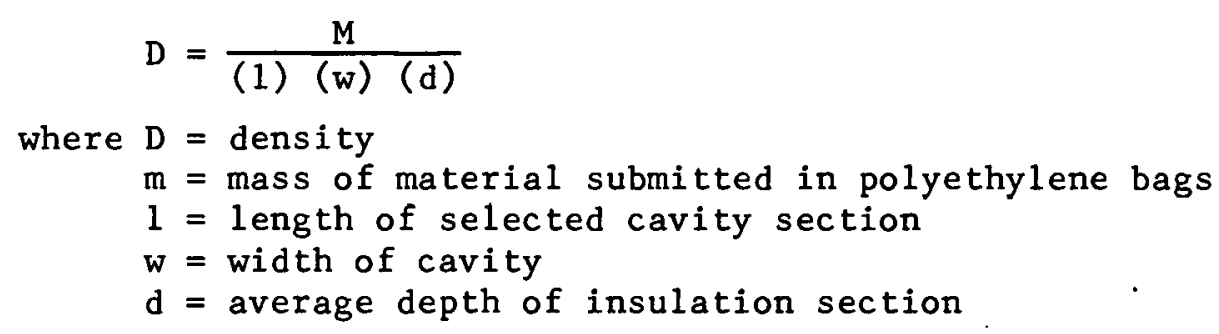

\section{Thermal Resistance}

The thermal resistance of the loose-fill cellulosic and mineral fiber insulations was determined in accordance with ASTM C518-76, "Steady-State Thermal Transmission Properties by Means of a Heat Flow Meter", using a 
commercially available heat flow meter apparatus. The upper and lower plates of the instrument were $24 \times 24$ inch blackened aluminum sinks, containing heaters which were temperature controlled with proportional/reset temperature controllers. Both plates were instrumented with a calibrated integrating heat flow transducer. The temperature of the upper and lower plates were controlled at 50 and $100 \mathrm{Deg}$. F respectively. The samples were placed within insulating containment rings, 3.5 inches thick for wall materials and 6 inches thick for ceiling materials. At equilibrium, the thermal resistance per inch was calculated as above.

\section{Moisture Content}

Duplicate 100 gram samples of the loose-fill insulation were placed in tared evaporating dishes and weighed. The sample was placed in an air circulating oven at $110 \mathrm{Deg}$. C for 48 hours, removed, placed in a dessicator until cool and reweighed. The percent mass loss assumed to be moisture content was calculated as:

$$
\begin{aligned}
& \text { \% mo1sture content }=\frac{\left(m_{i}-m_{f}\right)(100)}{m_{i}} \\
& \text { where } m_{i}=\text { initial mass } \\
& m_{f}=\text { final weight }
\end{aligned}
$$


APPENDIX 2

ERRATA SHEET FOR HCP/W2843-01

Stu Spinney, Dynatech R/D Company; John Weidt, John Weidt Associates

October 1979

\section{PAGE ITEM}

iii Tbl. of Contents, 7.3, Moisture Control

15 Section $7 \cdot 3$, MOISTURE CONTROL

21 Table 8.3, Attic Venting, Sample $17 \mathrm{c}$, none

34 Table 8.12, Sample 9C, 1\% Moisture Content

Sample 16C, 1\% Moisture Content Sample 18C, 1\% Moisture Content Sample 20C, $1 \%$ Moisture Content Sample 22C, 1\% Moisture Content Sample 29C, 1\% Moisture Content Sample 30C, 1\% Moisture Content Sample 31C, 1\% Moisture Content Sample 35C, 1\% Moisture Content. Sample 36C, 1\% Moisture Content Sample 37C, 1\% Moisture Content Sample 38C, 1\% Moisture Content Sample 39C, 1\% Moisture Content Sample 43C, 1\% Moisture Content

35 Table 8.12, Sample 47C, $1 \%$ Moisture Content Sampie 50C, 1\% Moisture Content Sample 52C, 1\% Moisture Content

37 Table 8.15, Sample 42C,

38 Table 8.16, Sample 8C, $1 \%$ Moisture Content Sample 42C, 1\% Moisture Content Sample 42C,

40 Table 8.18, Sample 24C, 1\% Moisture Content Sample 28C, 1\% Moisture Content

\section{CHANGE}

from Control to Content from CONTROL to CONTENT from none to average from $1 \%$ to $<1 \%$ from $1 \%$ to $<1 \%$ from $1 \%$ to $<1 \%$ from $1 \%$. to $<1 \%$ from $1 \%$ to $<1 \%$ from $1 \%$ to $<1 \%$ from $1 \%$ to $<1 \%$ from $1 \%$ to $<1 \%$ from $1 \%$ to $<1 \%$ from $1 \%$ to $<1 \%$ from $1 \%$ to $<1 \%$ from $1 \%$ to $<1 \%$ from $1 \%$ to $<1 \%$ from $1 \%$ to $<1 \%$ from $1 \%$ to $<1 \%$ from $1 \%$ to $<1 \%$ from $1 \%$ to $<1 \%$ Delete - Add to Table 8.11

from $1 \%$ to $<1 \%$ from $1 \%$ to $<1 \%$ Delete - Add to Table 8.12 from 1\% to $<1 \%$ from $1 \%$ to $<1 \%$ 


\section{INTERNAL DISTRIBUTION}

1. R. S. Carlsmith

2-51. M. C. Clary

52. R. G. Donnelly

53. T. S. Lundy

54. D. L. McElroy

55. J. N. Robinson

56. M. W. Rosenthat

57. A. C. Schaffhauser

58. D. B. Trauger

59. J. R. Weir, Jr.

60-63. Laboratory Records

64. Laboratory Records - RC

65. ORNL Patent Office

66-67. Central Research Library

68. Document Reference Section

\section{EXTERNAL DISTRIBUTION}

69-118. E. C. Freeman, DOE/BCS, Washington, DC

119-128. Mineral Insulation Manufacturers Association, 382 Springfield Ave., Summit, New Jersey 07901

129-203. John Weidt Associates, Inc., P. 0. Box 401, Chaska, Minnesota 55318

204. Assistant Manager, Energy Research and Development, DOE/ORO

205-231. Technical Information Center, P. 0. Box 62, Oak Ridge, TN 37830 